\title{
Jesús, el pueblo y la teología (II)
}

\author{
José M. Castillo, \\ Centro de Reflexión Teológica, \\ San Salvador.
}

\section{La leología y el pueblo}

\section{Cuándo, dónde y cómo nació la teología}

La teología cristiana nació antes que los evangelios, al menos tal como éstos han llegado hasta nosotros en su redacción definitival. Por eso, entre otras cosas, se ha podido decir con razón que san Pablo fue el primer teólogo cristiano2, es decir, a partir de él nació la teología. Por otra parte, sabemos que Pablo no convivió con Jesús y muy probablemente nació en Tarso (Hech 9, 11; 21, 39; $22,3)^{3}$ y se crió en un entomo helenista, en el que el griego era el idioma usual, su lengua matema4. Además, sus cartas fueron escritas desde la tradición del judaismo helenistas $\mathrm{y}$, por tanto, con una fuerte influencia de las corrientes culturales del helenismo del siglo primero. En este sentido, J. Vilchez, al explicar los influjos del helenismo en el libro de la Sabiduría, ha dicho acertadamente que "sería un iluso el que pensara que el helenismo, como conjunto de corrientes que configuraban la vida de los pueblos, no influyera en los judíos, como individuos y como comunidad, donde estaban organizados, en sus costumbres,

1. Como es sabido, antes que los evangelios se escribieron las cartas de Pablo, que, según parece, fueron redactadas entre los años 50 al 55. Cfr. S. Vidal, Las carlas originales de Pablo, Madrid, 1996, p. 22; H. Kōster, Introducción al Nuevo Testamento, Salamanca, 1988, p. 496.

2. H. Kūng, Grandes pensadores cristionos, Madrid, 1995, p. 17, con una bibliografia actualizada en pp. 213-214.

3. S. Vidal, op. cit., p. 22.

4. Cfr. H. Küng, op. cit., p. 19. Es significativo que tuvo doble nombre: el judío "Saulo" (Saúl) y el helenista "Pablo" (cfr. Hech 13, 9), pero en las cartas utiliza siempre el nombre helenista. Cfr. S. Vidal, op. cit., p. 23.

5. Cfr. S. Vidal, op. cit., p. 36. 
en su modo de vivir y de concebir la religión, la moral"6. Todo esto quiere decir, obviamente, que la teología cristiana nació en un ambiente cultural distinto (en cosas muy fundamentales) del ambiente en el que Jesús vivió y predicó su mensaje. A cualquiera se le ocurre pensar que este hecho tuvo que influir inevitablemente en la teología desde sus comienzos. Por supuesto, no se trata aquí ni siquiera de insinuar que Pablo adulteró el mensaje original de Jesús y menos aún que prescindió de él7. Pero sabemos que cualquier introducción al Nuevo Teslamento nos informa de que la teologia de Pablo es distinta, en puntos importantes, de la teología de los evangelios. En eso no hay duda. Pero la cuestión que aquí me interesa analizar es más concreta: se trata de saber si la cultura, en la que nació y se educó Pablo, condicionó de manera determinante su forma de entender y explicar el mensaje cristiano precisamente en la relación de ese mensaje con el pueblo.

Así, pues, lo primero que interesa recordar es lo que, en el siglo primero, se pensaba y se vivía a este respecto en la cultura helenista. Un autor bien conocido, y ya clásico en cuanto se refiere al estudio de aquella cultura, A. J. Festuguière, ha escrito: "Si se pregunta cuśl podría ser el ideal de un pagano griego o helenista, en el siglo primero", la respuesta es que ese ideal se centraba en "el hombre de buena familia (eugenés), de padres ricos, influyentes: se le enseñaba desde la infancia una moral esencialmente griega, forjada para el ciudadano libre, prohibida al esclavo o al bárbaro... Este ideal se centraba en la areté, la virtud, que se refiere no solamente al concepto nuestro de virtud moral, sino a todas las cualidades del cuerpo, del espírilu, del corazón, que hacen un gentelman, l'honête homme del siglo XVII y que procuran una justa gloria"8. Y el mismo Festugière señala la primera característica que eslo llevaba consigo: "El ideal griego fue siempre, en el mundo antiguo, el privilegio de los aristoi?.

6. J. Vilchez, Sabiduría, Estella, 1990, p. 74. Estc mismo autor cila a G. Verbekc, que afirma: "Aunque las comunidades de la Diáspora... formasen grupos apiñados en tomo a la sinagoga, centro de su vida religiosa, y su manera de vivir levantara una barrera, dificilmente franqueable entre ellos y los paganos, no podían, sin embargo, escapar complelamente al influjo de la civilización hclenística en la cual vivían sus miembros". L'Évolution de la doctrine du Pneuma du Stö̈cisme do s. Augustin, ParísLovaina, 1945, p. 223.

7. La postura límite, en esta dirección, scría la de Nielzsche cuando afirma que Pablo fue el auténtico fundador del cristianismo, y al mismo tiempo su falsificador. De manera que, "en el fondo sólo ha habido un cristiano, y ésc murió en la cruz". F. Nielzsche, El Anticrisio, Madrid, 1969, p. 66.

8. A. J. Festugière, L'idéal religieux des grecs et l'Evangile, París, 1981, p. 29. La primera edición de esla obra es de 1931.

9. El término aristos significa, ante todo, "el mejor" cn cuanto a nacimiento y rango. De ahl, el noble. Cfr. H. G. Liddell, R. Scolt, A Greek-English Lexikon, Oxford, 1969, p. 241. 
El esclavo, naturalmente, estaba excluido. El pobre, el hombre que trabajaba con sus manos, obligado cada día a ganarse el pan, no podía aspirar a este ideal. El que no tiene de qué vivir no debe soñar en conseguir la areté (Platón, Protag. $312 \mathrm{a}-\mathrm{d}$ ). Los jóvenes en los que piensa Platón son todos eugenés, pertenecen a la gentry de Atenas. Ahora bien, el número de ciudadanos de este tipo no fue nunca grande. Se conocian entre sí. Esto constituía un grupo bastante cerrado, un poco orgulloso. El consejo, tan frecuente, de escoger bien los amigos tenía un significado más social que moral. Los kakoi eran las gentes que no eran de recibo. Este exclusivismo, inconsciente o pretendido, era la marca distintiva de la educación griega"10.

Ahora bien, si todo esto era efectivamente así, lo más claro que de ello se deduce es que la cultura helenista, en la que nació la teología, era una cultura elitista, una cultura en la que los selectos y los privilegiados, por su condición social y económica, y también por su educación, eran los que ocupaban el centro y el poder, mientras que los dernás, la multitud, quedaban marginados $y$, con frecuencia, se veían profundamente despreciados. Esta es una de las cosas que llama poderosamente la atención en cuanto se leen los escritos más determinanles de las dos corrientes de pensaniento que más influyeron en el helenismo: el platonismo y el estoicismoll.

10. A. J. Festugière, op. cit., pp. 32-33. Es útil también, del mismo autor, su esludio: Le monde gréco-romain au temps de Notre-Seigneur, Paris, 1935.

11. Por supuesio, que en el helenismo (cl cenómeno cultural que da nombre a la ćpoca que va desde Alejandro Magno hasta Augusto) influyeron también los presocráticos, el epicureísmo y el gnosticismo, del que hablaré más adclante. Esto, sin contar la multilud de sectas y corricntes populares que abundaban en los diversos ambicntes. En cuanto al influjo del platonismo, se ha dicho que "los escritos de Platón, Jenofonte y varios filósofos posicriores fucron ampliamente extendidos por el mundo helcnístico... y muchas de sus idcas llegaron a ser $\mathrm{cn}$ cl siglo I a. C. propicdad común de los hombres cultos". S. Lunge, "The Wisdom of Salomon and Plato", JBL SS, 1936, p. 294 (cilado por J. Vilchez, op. cit., p. 78). Y por lo que sc refiere al cstoicismo, el mismo Vilchez cila a G. Verbckc: "cl pensamicnto del Pórtico penetraba de tal manera la atmósfera intelectual durante el periodo helenistico que se sufria el influjo sin darse cuenta de ello". L'Évolution de la doctrine du Pneuma du Stoicisme es s. Augustin, p. 233. Más aún, como sc ha escrilo rccicntementc, "cl csloicismo lue la doctrina más importante de la época helenística", de manera que "la filosofía estoica, próspera y pujante, no sólo dominó el panorama del pensamiento grecorromano durante más de cuatro siglos, sino que, además, sobrevivió al munđo hclerístico, inగluyó en el neopitagorismo, neoplatonismo y gnosticismo y penetró en el cristianismo a través de la influencia que cjerció sobre los Padres de la lglesia". A. López Eire, Diógenes Laercio. Los filósofos estoicos, Barcelona, 1990, pp. 58-59, con amplia bibliografía. 


\section{Platón: elogio de los "selectos"}

En cuanto al platonismo, sabemos que la sociedad es, para Platón, esencialmente "desigual", formada por grupos desiguales. Porque los hombres no son por naturaleza iguales12, ya que se trata de una sociedad conformada por tres estamentos: gobemantes, guerteros, campesinos y artesanos. En este sentido, dice Platón: "me doy cuenta... de que cada uno no tiene las mismas dotes naturales que los demás, sino que es diferente en cuanlo a su disposición natural: uno es apto para realizar una tarea, otro para otra"13. Esta desigualdad se manifiesta en una cosa concreta que, para Platón, es fundamental: la educación. La educación, dice Platón, no es para todos. Los dos estamentos superiores, gobernantes y guerreros, están sometidos a la educación. El tercer estamento, los campesinos y artesanos, no está capacitado para ser educadol4. Es más, se puede decir que el desprecio de Platón por las gentes de inferior condición llega al insulto. Por ejemplo, cuando afima que los gobernanles 15 no deben imitar a los hombres de más baja condición: mujeres y esclavos ${ }^{16}$, y tampoco a los trabajadores manuales 17. Y no los deben imitar porque, enire otras cosas, se avergonzarán de semejante imitación, "en parte por carecer de práctica en la imilación de tales personajes, en parte por sentir repulsión al hecho de amoldarse y adaptarse a los tipos de baja ralea"18. No es exagerado decir que Platón siente un auténtico desprecio hacia las gentes de más baja condición, que carecen de doles naturales 19 y de educación.

Por otra parte, este "clasismo elitista" lleva a Platón al convencimiento de que, para que la sociedad funcione bien, es indispensable que cada grupo social o estamento se quede en su sitio y no pretenda hacer lo que corresponde a otros, los que son capaces y están preparados para gobernar o hacer la guerra. Por eso, dice Platón: "¿no ves estas cosas también en el Estado, en el cual, sobre los apetitos que habitan en la multitud de gente mediocre, prevalecen los deseos y la

12. Cfr. U. Schmidt Osmanczik, "Platón como pensador político", en C. García Gual (ed.), Historia de la filosofía antigua, Madrid, 1997, p. 166.

13. Rep. II, $\mathbf{3 7 0}$ a.

14. Cfr. U. Schmidt Osmanczik, op. cit., p. 167. En este senlido, no se puede estar de acuerdo con R. G. Haerber, The Theme of Plato's Republic, S. Luis Missouri, 1944, pp. 57-59, que deficnde que la educación es para lodos, según Platón. Pero sabemos que Platón dice expresamente lo contrario repelidas veces en La República: 378 c, 387 c, 388 e, 394 e, 395 b, 398 e, 401 c, 402 c, 403 a, 410 a. Cfr. W. K. C. Guthrie, Historia de la filosofia griega, vol. IV, Plaıb́, Madrid, 1990, p. 437.

15. Rep. III, 395 a.

16. Rep. III, $395 \mathrm{~d}-\mathrm{e}$.

17. Rep. III, 396 a.

18. Rep. III, $396 \mathrm{~d}$.

19. Rep. II, 370 a. 
prudencia de aquellos que son los menores en número pero los más capaces?"20. De ahí que si "un artesano o alguien que por naturaleza es afecto a los negocios, inducido por el dinero o por la muchedumbre..., intenta ingresar en la clase de los guerreros, 0 alguno de los guerreros procura entrar en la de los consejeros y guardianes..., este intercambio y esta dispersión en múltiples tareas, creo, serán la perdición del Estado"21. Y el mismo Platón saca la consecuencia: "si has hallado para los que van a gobernar un modo de vida mejor que el gobernar, podrás contar con un Estado bien gobernado; pues sólo en él gobieman los que son realmente ricos, no en oro, sino en la riqueza que hace la felicidad: una vida virtuosa y sabia. No, en cambio, donde los pordioseros y necesitados de bienes privados marchan sobre los asuntos públicos, convencidos de que allí han de apoderarse del bien; pues cuando el gobiemo se convierte en objeto de disputas, semejante guerra doméstica e intestina acaba con ellos y con el resto del Estado"22. Evidentemente, esto significa que el Estado, según Platón, se sostiene sobre la base de que cada clase social no pretenda cambiar ni intente modificar el "orden establecido". Pero, además de eso, significa algo mucho más grave: que la "viđa virtuosa", la "vida sabia", los "asuntos públicos" y "el bien", todas estas cosas no son para "los pordioseros y necesitados". En otras palabras: el puebio, la gente, la multitud, no tiene derecho a aspirar al bien, a la virtud o al poder.

En un texto, elocuente como pocos, Platón expresa descaradamente lo que él piensa a este respecto: "cuando la multitud se sienta junta, apiñada en la asamblea, en los tribunales, en los teatros y campamentos o en cualquier otra reunión pública, y tumultuosamente censura algunas palabras o hechos y elogia otras, excediéndose en cada caso y dando grilos y aplaudiendo, de lo cual hacen eco las piedras y el lugar en que se hallan, duplicando el fragor de la censura y del elogio. En semejante caso, ¿cuál piensas que será el ánimo, por así decirlo? ¿Qué educación privada resistirá a ello sin caer anonadada por semejante censura o elogio y sin ser arrastrada por la corriente hasta donde ésı la lleve...?"23. Y Platón, consecuente con este modo de pensar, llega hasta el extremo de calificar a la "multitud" como la "gran bestia"24. Que nadie se sorprenda de semejante expresión. Este desprecio por el "pueblo" está en consonancia con el pensamiento de Platón. Lo afirma resueltamente en el Protágoras: "Porque la multitud, para decirlo

20. Rep. IV, $431 \mathrm{c}-\mathrm{d}$.

21. Rep. IV, 434 a-b.

22. Rep. VII, 521 a.

23. Rep. VI, 492 b.

24. Rep. VI, 493 a. No parece, pues, muy objetivo el juicio de W. K. C. Guthrie cuando alirma que "sin lugar a dudas, la aclitud platónica respecto del démos es realmente ambivalcnte". Op. cit., p. 481 , nota 166 . Por los textos citados, no parece ambivalcnte, sino claramente despectiva. 
en una palabra, no comprende nada, sino que corea lo que estos poderosos le proclaman"2s.

La razón última del problema (humano y social) que plantea este sistema de pensamiento está en que, para Platón, lo más sublime de la vida y la clave de todo lo demás está en la contemplación del Bien. Es el gran argumento del mito de la cavema: "el presente argumento indica que en el alma de cada uno hay poder de aprender y el órgano para ello, y que, asi como el ojo no puede volverse hacia la luz y dejar las tinieblas si no gira todo el cuerpo, del mismo modo hay que volverse desde lo que tiene génesis con toda el alma, hasta llegar a ser capaz de soportar la contemplación de lo que es, y lo más luminoso de lo que es, que es lo que llamamos el Bien"26. Pero, es claro, en las ideas de Platón no entraba que el pueblo, la multitud, la "gran bestia", pudiera llegar hasta esla altura. Los que no eran ni capaces de recibir "educación", ¿cómo iban a alcanzar la sublimidad de la "contemplación"?

Lo que llama la atención, en todo este razonamiento, es la concentración, en unas mismas personas (muy pocas), de tres cosas que nosolros hoy no vemos por qué han de ir juntas: la "virtud" (aretê), el "saber" (sophía) y el "poder" (krátos). Pero Platón es tajante a este respecto. Para él, en efecto, el "poder" y el "saber" tienen que concentrarse. Porque gobernantes y filósofos tienen que ser las mismas personas27. Ahora bien, lo que caracleriza al filósofo es el amor "al espectáculo de la verdad"28. Es decir, el "conocimiento" o la "sabiduría"29. Pero el "conocimiento" es "poder", en el sentido más fuerte de la palabra: "¿Dices que el conocimiento es un poder o en qué género lo ubicas? En ése: es el más vigoroso de todos los poderes"30. Pero, por otra parte, como ya he dicho antes, según Platón, gobernantes y (por tanto) filósofos deben ser solamente "los que son realmente ricos, no en oro, sino en la riqueza que hace la felicidad: una vida virtuosa y sabia"31. Es decir, en las mismas personas se tienen que concentrar el

25. Prof. 317 a; cfr. Gorg. 474 a. La indicación de este modo de pensar "está muy en consonancia con el pensar de Platón" es de C. Garcia Gual, Platón. Diálogos, I, Madrid, 1993, p. 518.

26. Rep. VII, $518 \mathrm{c}$.

27. Es la lesis que defiende en el Libro $V$ de la República: "A menos que los filosofos reinen en los Estados, o los que ahora son llamados reyes y gobernanles filosofen de modo genuino y adecuado, y que coincidan en una misma persona el poder político y la filosofia, y que sc prohiba rigurosamente que marchen scparadamente,... no habrá, querido Glaucón, fin de los males para los Estados ni tampoco, creo, para el género humano". Rep. V, p. $473 \mathrm{~d}$.

28. Rep. V, $477 \mathrm{~d}$.

29. Cfr. W. K. C. Gulhrie, op. cit., p. 468.

30. Rep. V, $477 \mathrm{~d}$.

31. Rep. VIl, 521 a. 
poder (gobernantes), el saber (filósofos) y la virtud (los que llevan una vida virtuosa y sabia).

De todo esto se siguen varias consecuencias. En primer lugar, sólo los ricos tienen acceso a la virtud, ya que ésta supone un aprendizaje que está al alcance únicamente de los que tienen posibilidades para ello: "Y esto lo hacen los que tienen más posibilidades, como son los ricos"32. En segundo lugar, el mal coincide con la ignorancia: "Pues ésla es la única acción mala: carecer de ciencia"ગ3. En tercer lugar -y esto es lo más importante-, la virtud es lo mismo que la superioridad en lodos los órdenes, el éxito social. Esto es cierto hasta tal punlo que, con frecuencia, los traductores del Protágoras dudan si traducir areté por "virud" o por "excelencia"34. En este sentido, Platón proclama a Protágoras: "Tú, que no sólo confías ser persona de bien...; lú eres personalmente hombre de bien y eres capaz de hacer a otros personas de bien. $Y$ tal confianza tienes en li mismo, que, mientras olros ocultan tal arte, tú lo proclamas claramente ante todos los griegos, llamándote sofista, y te has manifestado como maestro de educación y de virtud, siendo el primero en considerarte digno de recibir una paga por ese motivo"35. En definitiva, el que se considera el primero y se manifiesta como el primero, ése es el "maestro de la virtud". Se comprende que, para Platón, poder, saber y virtud son la misma cosa. Y, es claro, de semejante planteamiento no podía brotar sino una sociedad en la que los "virtuosos" tenían que ser los "selecios", los "poderosos". Así las cosas, al "pueblo", a la "multitud", no le quedaba olra salida que resignarse a vivir en la marginación e incluso en el desprecio. Nada tiene de extraño que un discípulo de Platón, Heráclides Póntico, llegara a pensar que, en la institución de la esclavitud griega, subyacía un elemento de fuerte vitalidad, aun a costa del prójimo, y otro factor de espiritualidad, que entendía el poder, no como fuerza bruta, sino como disposición racional, base necesaria, por otra parte, para el bios theoretikós, la vida contemplativa 36 .

32. Prot. $326 \mathrm{c}$.

33. Pror. 345 b.

34. Por cjemplo, C. C. W. Taylor prefiere traducir por "excelencia", Asi, cn su Platon, Protagoras, translated with notes, Oxford, 1975. Sin embargo, como indica C. Garcia Gual, "adoptar siempre el término 'excelencia', como si fuera un equivalente exacto del vocablo griego (arete)... no me parece tampoco una óplima solución”. Plaıón. Didlogos, I, Prold́goras, Madrid, 1993, p. 522, nola 25. En todo caso, hay que advertir que la areté, en el Protágoras, no es equivalente a la virtud cristiana, sino que se asemeja, más bien, a la virtus latina, como indica cl misno Garcja Gual. loc. cit. Pero lo que es indiscutible es que areté no es lo mismo que téchné (técnica), como ha pretendjdo W. K. C. Guthrie (op. cil., p. 212). Semejante identilicación es negada expresamente por Platón. Prot. $324 \mathrm{e}-325$ a.

35. Prot. 348 c -349 a.

36. Aten. XII, 512 a., cjiado por J. S. Lasso de la Vega, Ideales de la formación griega, Madrid, 1966, p. 91. 


\section{Estoicismo: los privilegios de los "sabios"}

Como es sabido, los escritos de los estoicos antiguos, Zenón (siglo IV a. C.), Cleantes y Crisipo (siglo III a. C.), no se han conservado. Y sólo conocemos los fragmentos que nos pudo transmilir Diógenes Laercio (siglo Ill d. C.) en su Colección de las vidas y doctrinas de los filósofos 37 . Pero, como bien ha indicado M. Isnardi Parente, "mientras no exista una nueva edición completa, dedicada a toda la Stoa antigua en su conjunto, de fragmentos y testimonios, la recolección de H. von Amim, Stoicorum Veterum Fragmenta, seguirá siendo base imprescindible para toda obra ulterior de conjunto relativa a esta escuela"38.

Por otra parte, no voy a ponderar ahora la importancia que tuvo el esloicismo, desde su fundador, Zenón de Citio, hasta los autores más conocidos del llamado estoicismo "imperial" o la Nueva Estoa Romana, Séneca, Epicteto y Marco Aurelio. Baste recordar que, como se ha dicho, seguramente con bastante razón, el estoicismo fue "el movimiento filosófico más importante durante cinco siglos"39.

No se trata aquí, como es obvio, de exponer (ni siquiera en síntesis) el conjunto del pensamiento estoico. Para lo que pretendo, en este trabajo, me limito a recordar que los estoicos se interesaron sobre todo por la élica. Y eso sin duda porque, en su contexto histórico, lo que más preocupaba era la conexión entra la teoría y la práctica40. Ahora bien, el principio delerminante de toda la ética estoica era éste: "vivir en armonía con la razón" o, lo que es lo mismo, vivir según una "razón armoniosa" (thên hómologouménos)41. Según Crisipo, se trataba de "vivir en conformidad con la naturaleza"42. Pero, por otra parte, la gran dificultad para que el hombre viva en esta amonía consigo mismo (que es lo que lleva a la virtud) proviene de las cuatro pasiones fundamentales, que son irracionales y contrarias a la naturaleza, incluso cuando parten de una tendencia natural o racional43. Eslas cuatro pasiones son, ya desde Zenón, el "placer"

37. Texlo fijado por H. S. Long, Diogenis Laertii, Vitae philosophorum II, Oxford, 1964. Traducción del Libro VII, que trata sobre lodo de Zenón, por A. Lópcz Eire, Diogenes Laercio. Los filossofos estoicos, Barcelona, 1990.

38. Stoici antichi, Torino, 1989, Vol. I, p. 95. Cfr. A. J. Cappellelli, Los estoicos antiguas, Madrid, 1996, p. 9. Como es bien conocido, la obra de Hans von Arnin apareció en Leipzig, en 1902 y 1905 . Y se ha vuelto a imprimir en Stuttgart, en 1964. Se cita siempre bajo la sigla $S V F$.

39. M. J. Imaz, "Sobre el estoicismo. Rasgos generales y figuras centrales", en C. Garcia Gual, Historia de la filosofia antigua, Madrid, 1997, p. 297, con bibliografía básica en pp. 316-317. Bibliografía más amplia en A. Lopez Eire, op. cit, pp. 14-17.

40. Cfr. M. J. Imaz, op. cit., p. 298.

41. SVF I, pp. 179, 552; III, 5; 12; 15. Según Séneca es la "vita concors sibi" (Epist. 89, 15).

Cfr. M. Spanneut, Permanence du Sioicisme. De Zénon d Malraus, Paris, 1973, p. 38.

42. SVF III, p. 4. En este principio insiste, con razón, A. López Eire, op. cit., pp. 15-16.

43. SVF I, p. 205; III, Pp. 377, 391, 412, $462,479$. 
(hedoné), la "tristeza" (lype), el "deseo" (epithymía) y el "miedo" (phobos)44. Pero, en realidad, con estas palabras se expresan cuatro "categorías de pasiones", de las que resultan en concreto 76 pasiones, cada una de ellas designada con un nombre específico y acompañada de su correspondiente defínición 45 .

Ahora bien, si para vivir en completa armonía con la naturaleza y la razón era absolutamente necesario dominar y vencer las 76 pasiones, ya que sólo así se podía llegar a ser el hombre cabal y modélico (apathès)46, difícil lo tenían los antiguos estoicos para alcanzar semejante perfección. Sobre todo, si tenemos en cuenta que, por ejemplo, una de las cuatro categorías de pasiones era el "deseo"; y la lista completa de "deseos", que de ahí brotaban, llegaba hasta 31 "pasiones" que era necesario dominar47, entre las que se enumeraban, pongo por caso, himeros (deseo de un amigo ausente) y pothos (deseo de la persona amada ausente), con lo que se venían a poner en cuestión temas tan profundamente humanos como el sentimiento por la ausencia y la nostalgia48. Así las cosas, los primeros esloicos encontraron una solución que, por más extraña que nos resulte, a ellos les proporcionó una salida que parecía resolver la situación. Y es que dividieron a los seres humanos en dos calegorías de personas: "Zenón y sus discípulos distinguen entre dos razas (génè) de hombres, los sabios (sophoi) y los villanos (phouloi). La raza de los sabios practica constantemente la virtud, la de los villanos, el vicio"49. Es verdad que, en el llamado "estoicismo medio", Posidonio (135-155 a.C.) intentó buscar una solución intermedia, hablando de

44. SVF I, p. 211; III, pp. 378, 381, 386, 391, 412, 444. Cfr. A. Lopez Eire, Dibgenes Laercio. Los filósofos esioicos, VII, 110, p. 183.

45. La lista, debidamente clasificada, de estas 76 pasiones, se encuentra en el esludio de Maria Daraki, Une religiasité sans Dieu. Essai sur les sticiens d'Athènes et saint Augustin, Paris, 1989, pp. 79-92. Como indica esta autora, el tema de las pasiones particulares representa un capilulo casi inexplorado del estoicismo antiguo (op. cit., p. 80). La lista más completa de estas pasiones es la que ofrece Andrónico de Rodas, pero debe ser completada por la de Slobeo y por la de Diógenes Lacrcio. La lista de Andrónico se encuentra en A. Gilbert-Thirry, Pseudo-Andronikos de Rhodes, Peri Pathon, Leyde, 1977.

46. SVF III, p. 448.

47. La lista completa de los 31 "deseos", debidamente clasificados, y con la indicación de los autores que los proponen, en M. Daraki, op. cir., pp. 82-83.

48. Cfr. M. Daraki, op. cir., p. 85.

49. SVF I, p. 216. La traducción de phaulos por "villano" responde al significado de este término, que, cuando se aplica a personas, quiere decir, en primer lugar, "de bajo rango", "vulgar". Cfr. Liddell - Scott, A Greek-English Lexikon, London, 1968, que traduce: low in rank, mean, common. Es decir, indica no sólo la idea moral de maldad, sino antes que eso la condición social del que pertenece a lo que en castellano diríamos el "populacho" o la "gentuza". 
los prokoptontés, "los que están en camino de hacer progresos"50. Pero eso mismo nos está diciendo hasta qué punto el ideal estoico se mantuvo en la división de "sabios" o virtuosos y "villanos" o viciosos. De hecho sabemos, por ejemplo, que Séneca afima aceptar las divisiones tradicionales de la Stoa en lo que se refiere a la moral, la física y la lógica5i.

Esto supuesto, lo que más llama la atención en todo este asunto es que, de acuerdo con la división establecida, los estoicos afirmaban que, desde el punto de vista social, los "sabios" (sophoi) son ricos52 y poseen todos los bienes53, mientras que los "villanos" (phauloi) son pobres y no poseen nada54. El "sabio" es libre porque es dueño de sí mismoss. Por el contrario, el "villano" es esclavo porque está privado del dominio propio56. Desde el punto de vista intelectual, el "sabio" posee la verdadera ciencia a título exclusivo57, en tanto que el "villano" es el ignorante por excelencia58 y no tiene acceso alguno a la ciencia59. Finalmente, por lo que respecta a la religión, los "sabios" son los amigos de los dioses 60 , mientras que los "villanos" son ateos, en cuanto que se oponen a lo divino61. Y es que, en definitiva, el "sabio", no sólo está predispuesto por naturaleza a la práctica de la virtud62 y es un individuo al que le repugnan los actos viciosos63, sino que además todos sus aclos son virtuosos64. En el extremo opuesto, el "villano" se complace en los vicios65 porque no está dispuesto, en modo alguno, a la virtud66.

Sin duda alguna, las cosas no eran así en la realidad de la vida. Quiero decir: ni los "sabios" eran tan ejemplares ni los "villanos" tan indeseables. De manera que ni los fundadores del estoicismo vivieron de manera tan excelsa. Crisipo es

50. Para este punto, cfr. el estudio de M. Lalfranque, Posseidonios d'Apamée, París, 1964. La documentación sobre este autor, en L. Edelstcin, I. G. Kidd, Posidonii fragmenta, Cambridge, 1967.

51. Epist. LXXXIX, 9. Insiste en su fidelidad a Zenón o Crisipo, en De otio, III, 1.

52. SVF III, p. 603.

53. SVF III, pp. $590,625$.

54. SVF III, pp. 593, 674.

55. SVF III, Pp. 591, 335.

56. SVF 11, pp. 355, 593, 599.

57. SVF 1, p. 66; III, pp. 112, 657.

58. SVF III, p. 663.

59. SVF III, p. 548.

60. SVF III, p. 216.

61. SVF III, p. 606.

62. SVF III, p. 366.

63. SVF III, p. 649.

64. SVF III, p. 643.

65. SVF III, p. 684.

66. SVF III, p. 682. 
terminante a este respecto: "Nosotros los hombres, todos insensatos, no podemos nada más que ceder a las apariencias"67. Con razón, Plutarco calificó todo esto como "estupideces de los estoicos"68. Pero lo que de verdad interesa en toda esta cuestión no es si, efectivamente, los hombres eran o no eran así. Lo importante es la mentalidad que todo esto expresa. $Y$ lo que aquí se expresa es una escala de valores según la cual las gentes sencillas del pueblo, los pobres, los ignorantes, los esclavos, los que con toda razón pueden ser calificados como "villanos", o sea la "gentuza", todas esas personas ni viven ni pueden vivir "en armonía con la naturaleza y con la razón". Y esto es así porque el pueblo (los "villanos"), precisamente porque es “ignorante", nunca podrá ser "virtuoso". Así eran las cosas para la mentalidad estoica. Como indica muy bien María Daraki, "los estoicos definen la ciencia en términos de virtud, y la virtud en términos de ciencia"69. "La virtud es una: la ciencia del bien y del mal"70. Lo que Crisipo afima de manera más tajante: "La virtud es una: la ciencia"71. O sea, la ciencia es el fin supremo, el telos72. De esta manera, lo "epistemológico" se fusiona con lo "ético". Porque la ciencia es "el bien en si"73. Pero es claro que, desde el momento en que ciencia y virud son la misma cosa, el pueblo ignorante se ve condenando al vicio o, to que es lo mismo, al desprecio. $\mathrm{Y}$ los únicos que tienen derecho a ser y vivir como personas dignas y razonables son los "sabios".

La conclusión que se sigue inevitablemente de todo esto es trágica. Si la sabiduría y la virtud están deleminadas por el dominio de las pasiones y ser virtuoso es lo mismo que dominar los "deseos", los "placeres", las "tristezas" y los "miedos" (las cuatro categorías de pasiones), entonces es cierto lo que se ha dicho: "El estoicismo fue justamente la filosofía que, en lugar de la acción en cuanto praxis, propuso la acción en cuanto ascesis, o sea como acción sobre sí mismo. A partir de este criterio, el Sabio es el sujeto activo, el 'ciudadano aclivo' de la Gran Ciudad. El Villano queda excluido de todo eso, en cuanto que es el 'hombre pasivo', entregado a sus impulsos"74.

67. SVF III, pp. 657, 666, 668 .

68. Sroicorum repugnantiae, p. 31. Cfr. SVF III, p. 668. Citado por M. Daraki, op. cis., p. 55.

69. Op. cil., p. 126.

70. $S V F$ l, p. 374.

71. SVF III, p. 256. Esto es cicrlo hasta tal punto que las tres virtudes fundamentales de la tradición griega, phrónesis (pondcración), sophrosyne (sabiduría) y andreia (valor) eran clasificadas por los estoicos entre las "ciencias" (SVF III, p. 266), mientras que consideraban como "virtudes" la "dialćctica", la "retórica" y la "física" (SVF III, p. 267). Cfr. para todo esto, M. Daraki, op. cit., p. 126.

72. SVF II, Pp. 411, 421; III, p. 25.

73. SVF III, p. 112. M. Daraki, op. cir., p. 127.

74. M. Daraki, op. cit., p. 164. 
A mediados del siglo I (d. C.), justamente cuando san Pablo desarrolla su actividad misional más intensa y escribe sus cartas, Séneca está en Roma como pretor y es designado por el emperador Claudio preceptor de Nerón75. Ahora bien, si algo hay claro en el pensamiento de Séneca, es que el ideal estoico se encama en el "sabio", es decir, en el hombre que ha extirpado sus pasiones. Es la idea que desarrolla en todo el tratado De constantia sapientis76. Por eso, el "sabio" es el hombre lleno de "confianza en si"77, que vive en una "serenidad impasible"78, un alma como las cosas que están más arriba que la luna, siempre serena79. Esto explica que, como se ha dicho, toda la obra de Séneca está orientada hacia aquellos que están lejos de ser sabios, a los "aprendices de la sabiduría", a los proficientes, a los que describe los grados de la escala de la perfección80. Es verdad que en Séneca no se advierte el profundo desprecio por la "multitud" (Platón) o por el "populacho", la "gentuza", phauloi (estoicos de Atenas). Pero no es menos cierto que, en el fondo, nos encontramos con el mismo planteamiento: si el ideal es el "sabio" y sabio es el que extirpa las propias "pasiones", resulta exactísima la conclusión de A. De Bovis: la vida aparece "mucho más como una actividad centrada en el yo, que como una acción orientada hacia Dios"BI. Porque, en definitiva, no se trata de cambiar la sociedad, el mundo, sino de conseguir uno mismo la felicidad: "Hazte feliz a ti mismo"B2. Por un camino o por otro, nos encontramos de nuevo con la conclusión de antes: los estoicos propusieron, en lugar de la acción como praxis (para transformar la historia, la sociedad, la vida de los seres humanos...), la acción como ascesis (para cambiarse cada cual a sí mismo). Los intereses del yo triunfaron sobre los intereses de los que peor lo pasan en la vida.

75. Cfr. P. Auberque, J. M. André, Sénèque, París, 1964; H. Cancik, Untersuchungen zu Senecas epistulae morales. Hildcshcim, 1967; E. Elorduy y otros, Estudios sobre Séneca, Madrid, 1966; A. De Bovis, La Sagesse de Sénèque, Paris, 1948; J. C. García-Borrón, Séneca y los estoicos. Una contribución al estudio del senequismo, Barcelona, 1956; I. Hadot, Seneca und die griechisch-römische Tradition der Seelenleisung, Berlin, 1968; M. Spanncut, Permanence du Stoicisme. De Zénon à Malrawe, Paris, 1973, pp. 56-74.

76. Por cjemplo VI, 8. De ahí que cl sabio cs "semejanle a Dios". Op. cit., VIII, 2-3.

77. Epist. CI, 2.

78. De vita beata, $111,4$.

79. Epist. LIX, 16.

80. Epist. LXXI, 35-36; LXXV, 8-15; De const. sap., XIX, 4; De vita beasa XVI, 3. M. Spanneul, op. cit., p. 63.

81. Op. cir., p. 230.

82. Epist. XXXI, 5. 


\section{El primer teólogo cristiano}

¿Conoció san Pablo directamente la filosofía de Platón o las ideas de los estoicos? No lo sabemos. Ni sé si eso se podrá conocer alguna vez ${ }^{83}$. Lo único que parece seguro es que Pablo nació y se educó en un ambiente obviamente influenciado por el helenismo de su tiempo84, como ya indiqué antes. Además, las cartas de Pablo dan a entender que poseía un dominio bastante grande de la lengua griega y un conocimiento de las concepciones filosóficas populares y del arte de la retórica, lo cual hace suponer una formación escolar helenista, dentro de la tradición estoica por entonces muy difundidass.

Esto supuesto, la pregunta que aquí se plantea es: ¿qué importancia y qué significación tiene el pueblo en la teología de Pablo? Esta pregunta lleva inevitablemente a preguntarse también: ¿qué interés muestra Pablo por el pueblo?, ¿qué le preocupa a Pablo cuando, en sus cartas, aparece el tema del pueblo? Debo indicar que es lógico hacerse estas preguntas, después de haber visto, en la primera parte de este trabajo, que la relación de Jesús con el pueblo es central en la teología de los evangelios, concretamente en los sinópticos. Si en la vida de Jesús esto fue tan determinante, no sólo para su mensaje, sino también para su destino final, resulta inevitable preguntarse: ¿siguió Pablo esta misma línea de pensamiento y de actuación? Y si aparece que, en las enseñanzas de Pablo, las cosas no fueron igual, ¿por qué ocurrió eso? $Y$, sobre todo, ¿qué es lo que eso significa para la teología?

Empiezo por lo más claro: el pueblo como "multitud", "gente" (óchlos), tan decisivo en los evangelios, no aparece ni una sola vez en los escrilos de Pablo. Sin duda, esto era algo que ni le interesó ni le preocupó. Es sorprendente que Pablo tampoco utilice el término démos, que designa al "pueblo", a la "muchedumbre", por contraposición a los notables y poderosos de la sociedad, como he

83. En cuanto a la relación de Pablo con cl cstoicismo se han plantcado diversas hipótesis, incluso la posibilidad de una comunicación epistolar entre el apóstol y Séneca. Pero la verdad es que no se ha llegado a ninguna conclusión segura. Cfr. P. Benoit, "Sénèquc et saint Paul", Rev. Bibl. 53, 1946, pp. 7-35; E. Elorduy, "Estoicismo y cristianismo", Est. Ecles. 18, 1944, pp. 375-411; A. J. Festugière, "Saint Paul et Marc-Aurèle", en L'Idéal religieux des Grecs et l'Evangile, París, 1932, pp. 264280; A. Jagu, "Saint Paul et le stoïcisme", Rech. Sc. Rel. 51, 1953, pp. 535-549; M. Pohlenz, "Paulus und die Stoa", Zeitschrift Neutest. Wissenschaft 42, 1949, pp. 69 104; J. N. Sevenster, Paul and Seneca, Leyde, 1961.

B4. Que no se educó en Jerusalén y, por tanto, no fue discípulo de Gamaliel, se deduce de $G$ al 1, 22. En cstc punto, el dato de la carta a los Gálatas es más fiable que Hechos 22, 3; 26, 4-5. Cfr. S. Vidal, Las cartas originales de Pablo, p. 23. Tampoco parece que fucra Larisco, sino "en cuanlo a la observancia de la ley, farisco" (Fil 3, 5). Cfr. S. Vidal, op. cil., p. 309.

85. Así lo hace notar H. Köster, Introducción al Nuevo Testamento, p. 606. 
dicho al explicar el pensamiento de Platón en la Repúblicaßr. Pablo habla del pueblo utilizando dos palabras: lás y, sobre todo, éthnos. Laós, que se encuentra unas 200 veces en los LXX, como el título honorífico de Israel (el "pueblo de Dios"), expresa que la Iglesia ha pasado a ser ese "pueblo escogido", los "hijos de Dios vivo" (Rom 9, 26). De hecho, todos los textos de Pablo, en los que aparece el laós, remiten a citas del Antiguo Testamento en las que, de una manera o de otra, se habla de la elección divina, que se prolonga en la comunidad cristiana87. Pero, como es bien sabido, el tema del pueblo interesa a Pablo, sobre todo, en el sentido de éthnos. Esta palabra, que tuvo originalmente en el griego clásico un significado peyorativo, designa al "extranjero", ya desde Aristótelesî. Por eso, en los LXX aparece insistentemente este término para expresar la contraposición entre Israel, como pueblo escogido, y los "gentiles", los otros pueblos ${ }^{89}$. Esto explica que Pablo, en sus cartas, eche mano de esta palabra más de 50 veces, ya que él se considera el apóstol de los paganos (Gal 1, 16; 2, 7-9; Rom 1, 5; cfr. Ef 3, 1-13), no obstante la oposición de los judíos (1Tes 2, 16). Pero lo que Pablo quiere destacar, al tratar todo este asunto, es que tanto los que nacen judios como los que nacen paganos, si abrazan la fe en Jesucristo, unos y otros pertenecen al pueblo de Dios (Rom 4, 17; Gal 3, 7.13s; 26-29).

Lo que se puede deducir, por lo pronto, de esta simple recopilación de los términos que usa Pablo al referirse al pueblo, es que al primer teólogo cristiano le interesó el asunto del pueblo como problema teológico. Porque, efectivamente, hablar del "pueblo", en las siluaciones concretas que se presentaron en los primeros años de la Iglesia naciente, era hablar de problemas "teológicos" muy importantes y urgentes, porque eran cosas que había que aclarar cuanto antes. Estaba, en primer lugar, el problema de saber qué relación había entre la nueva Iglesia y el antiguo pueblo de Dios, es decir, si lo que nació a partir de Jesús tenía o no tenía que ver con la elección divina que se hizo de un "pueblo" desde los remotos tiempos de los patriarcas. Y estaba, en segundo lugar, el acuciante problema que se les planteaba a unos judios, que querían ser fieles a otro judío, Jesús el Nazareno, que murió condenado y rechazado por los máximos dirigentes de Israel. Lo que planteaba preguntas gravísimas. Por ejemplo, el mensaje de Jesús, ¿se dirigía sólo a los judíos o era para todo el mundo? Y si era para todo el mundo, ¿los no judios tenían que someterse a las leyes del judaísmo o bastaba creer en aquel Jesús que habían crucificado los dirigentes del pueblo escogido? Eslas preguntas no plantean dificultad alguna para nosotros ahora. Pero cuando

86. Cfr. lambién H. Bietenhard, "Pueblo", en L Coenen, E. Beyreuther, H. Bietenhard, Diccionario Teologico del N.T., Vol. Ill, p. 437.

87. Rom 9, 26 (Os 2, 25).26 (Os 1, 10); 10, 21 (Is 65, 2); 11, 1-2 (Sal 94, 14); 15,10 (Deul 32, 43); 1Cor 10, 7 (Ex 32, 6); 14, 21 (1s 26, 11); 2Cor 6, 16 (Lev 26, 12).

88. Pol. 132 b, 10.

89. Cfr. H. Bielenhard, op. cis., p. 439. 
Pablo se pasó (bruscamente) del judaísmo más fanático a la nueva secta (la Iglesia), que estaba dando sus primeros pasos, toda esta problemática tuvo que acaparar hasta tal punto su atención y sus intereses más fuertes, que resulta perfectamente comprensible su constante preocupación por el problema del pueblo como "pueblo de Dios"; y también su empeño por dejar bien clara la llamada que Dios hacía a los otros "pueblos", los paganos, porque Dios los quería y los quiere con los mismos derechos que el "pueblo" de la primera elección. Todo esto es bien conocido para cualquier esludioso de los origenes del cristianismo.

Pero es claro que, a la vista de esta confusa y delicada situación, a nadie le debe sorprender que Pablo centrara sus preocupaciones en el pueblo como problema teológico, en el sentido indicado. ¿Quiere esto decir que a Pablo no le preocupó ni le interesó el pueblo como problema humano? Quiero decir, ¿es que a Pablo no le importó el hambre del pueblo, la pobreza del pueblo, el sufrimiento del pueblo, la opresión del pueblo? Más aún, ¿es que, en la mentalidad de Pablo, el hambre, la pobreza, el sulrimiento y la opresión no son problemas "teológicos" y, por tanto, son asuntos de los que el "teólogo" no tiene por qué preocuparse?

Que Pablo se interesó por el hambre de los pobres, es cosa que sabemos por la colecta que organizó, con tanto empeño (Gal 2, 10), para ayudar a los cristianos de Jerusalén ( $c f r$. 1Cor 16, 1ss; 2 Cor 12, 18) ${ }^{90}$. Que en la teología de Pablo ocupa un lugar importante "lo necio del mundo", "lo débil del mundo", "lo plebeyo del mundo", "lo que no exisle" ni cuenta para nada (1Cor 1, 27-28), es también algo bien conocido y que, a mi manera de ver, es una de las grandes cuestiones para entender, no sólo la teología de Pablo, sino cualquier teología que pretenda ser cristiana". Más aún, que, en la mentalidad de Pablo, lo "teológico" y lo "sociológico" no se pueden separar o desentender mutuamente, es seguramente la conclusión más imporlante que se desprende del famoso problema que el apóstol quiso resolver en la comunidad de Corinto cuando se enteró que ricos y pobres, divididos y enfrentados, pretendian celebrar juntos la eucaristía (1Cor 11, 17-34). La idea de Pablo es que la "cena del Señor" (lo "teológico") no se puede celebrar cuando "ricos y pobres" (lo "sociológico) son reali-

90. Cfr. D. Georgi, "Die Geschichıc der Kollecte des Paulus für Jerusalen", Theologische Forschung 38, Hamburg, 1965.

91. Esto justamente es lo que he pretendido demostrar al analizar el problema hermenćutico que los pobres planican a la tcología. Y tambićn la significación de la "dcbilidad" (asthéneia) para el quchacer tcológico. J. M. Castillo, Los pobres y la seología. ¿Qué queda de la teología de la liberación?, Bilbao, 1997, pp. 32-35 y, sobre todo, pp. 109-112. 
dades que no están debidamente integradas la una en la otra92. Y conste que Pablo no dice que, en esas condiciones, "no se debe" celebrar la eucaristía, lo cual ya sería muy fuerte. Pero no. Lo que Pablo afima es que, cuando existe tal división y el consiguiente conflicto, eso ya "no es la cena del Señor" (oúk estin kiriakon deipnon phagein) (1Cor 11, 20). La cosa es clara: a Pablo le interesó mucho el problema de los pobres y se preocupó por el sufrimiento y los intereses del pueblo. Esto nadie lo puede poner en duda.

Y sin embargo, habría que estar ciegos para no darse cuenta de que la leclura de las cartas de Pablo planiea un serio problema, precisamente en lo que se refiere a la relación de la teología con el pueblo. Ante todo, porque resulta inevilable pensar que, si Pablo no menciona ni una sola vez al óchlos o al démos, eso tiene que ser porque el "pueblo", en cuanlo tal, el "pueblo" sin más, sin referencias "teológicas" o "biblicas", era algo que no entraba en sus cálculos, en sus intereses, en lo que a él le preocupaba cuando se ponía a pensar y a escribir sobre Dios, sobre Jesucristo o sobre la salvación cristiana. Esto, a mí por lo menos, me parece que es bastante claro.

Pero el problema está en saber por qué Pablo no se interesa por el pueblo, por la gente, como se interesó Jesús, al menos tal como eso aparece en los evangelios. ¿Se trata de una mera diferencia de vocabulario? ¿Es asunto simplemente de temáticas distintas? ¿Podemos despachar esta cuestión mediante la fácil escapatoria que consiste en decir que la leología de Pablo es distinta de la teología de los sinópticos? A mí me parece que decir esas cosas es lo mismo que no afrontar el problema. Porque se trata de un problema muy real. Y, a mi manera de ver, muy serio. Porque, como voy a decir enseguida, toca el centro mismo del mensaje de Jesús. ¿Qué decir entonces?

Empiezo por ahí, precisamente por el centro. Sabemos, en efecto, que el centro del mensaje, según la teología de los evangelios sinópticos, es el reino de Dios. De esto se ha escrito tanto, en los últimos cincuenta años, y es una cosa que se ha repetido de tantas maneras, que no voy ahora a insistir más en algo que es de lo más elemental en la teología actual bien informada. Como se ha dicho muy bien, resumiendo toda esta enorme literatura leológica, el reino de Dios es "el punto central en el mensaje de Jesús"93. Ahora bien, lo primero que llama la atención es que, mientras los tres evangelios sinópticos hablan más de cien veces del reino de Dios, en las carlas de Pablo se habla de ese asunto sólo

92. Cfr. el excelente esludio de G. Theissen, "Integración social y acción sacramental. Un análisis de 1Cor 11, 17-34", en Estudios de sociologia del cristianismo primitivo, Salamanca, 1985, pp. 257-283.

93 A. Lindemann, "Herrschaft Gottes/Reich Gottes, V, Neues Testament und spätantikes Judentum", en Theologische Realenryklopädie, Vol. XV, p. 201, con amplísima bibliografía en pp. 215-218. 
once veces (Rom 14, 17; 1Cor 4, 20; 6, 9-10; 15, 24-25.50; Gal 5, 19-21; Ef 5, $3-5$; Col 1, 11-14; 4, 11; 1Tes 2, 10-12; 2Tes 1, 4-5)94. Pero la diferencia de fondo no está en la utilización más o menos frecuente de la expresión "reino de Dios". La diferencia (que hace pensar) es con quién relacionan los sinópticos el reino de Dios, por una parte, y con quién relaciona Pablo el reino de Dios, por otra parte.

Ahora bien, si algo quedó claro, en la primera parte de este trabajo, es que quien acogió y aceptó el mensaje de Jesús, el mensaje del reino, fue el "pueblo" (óchlos), es decir, las gentes marginales de aquella sociedad, concretamente los enfermos y endemoniados (Mt 4, 23-25 par; 10, 7-8 par), los pobres (Lc 6, 20; Mt 5, 3), los que carecen de todo derecho y de toda dignidad, (niños) (Mt 18, 14; Mc 10, 14-15; Lc 18,16), de manera que sólo los que se hacen como esas personas pueden entrar en el reino (Mi 18, 3 par). Más aún, Jesús llega a decir que, en el banquete del reino (Mt 22, 2 par), entran los vagabundos de los caminos (Mt 22, 9 par), lo mismo "malos que buenos", poneroús te kaí agathoús, (Mt 22, 10) y, lo que es más sorprendente, que quienes entran por delante de los más poderosos y notables son los publicanos y las prostitutas (Mt 21, 31). ¿Con quién relacionan los evangelios sinópticos el mensaje de Jesús sobre el reino de Dios? Sin duda alguna, con la gente de más baja condición, desde el punto de vista económico, social, cultural y hasta moral. Esto quiere decir obviamente que el reino que predicó Jesús no era un mensaje para "selectos", ni socialmente, ni culturalmente, por supuesto. Pero ni siquiera para personas moralmente intachables.

Y aquí, precisamente, es donde está la diferencia (que hace pensar) entre la teología de Pablo sobre el reino y la teología de los sinóplicos sobre ese mismo asunto. Ya he recordado los once textos en los que Pablo menciona la expresión "reino de Dios"95. Pues bien, si se exceptúa Colosenses 4, 11, en donde Pablo se refiere simplemente a sus "colaboradores en el reino de Dios", los otros diez textos se dividen en dos grupos: siete que se refieren a la conducta moral de los cristianos y tres que relacionan el reino de Dios con el poder 96.

En los textos en los que Pablo interpreta el reino de Dios desde el punto de vista de la moralidad, hay tres que afiman la presencia del reino en los cristianos que se comportan de una manera "santa, justa e irreprochable" (os ósios kai dikaíos kai amémptos)... “de manera digna de Dios, áxios toú theoú (1Tes 2, 10-

94. En las cartas pastorales se habla del reino en 1 Tim 1,$17 ; 6,15 ; 2 \mathrm{Tim} 4,1.18$.

95. En Col 1, 14 habla del "reino de su Hijo querido". Y en Ef 5, 5, del "reino de Cristo y de Dios".

96. Con razón se han destacado los dos aspectos desde los que Pablo ve el reino de Dios: el poder (en dynómee, in Macht) y las listas de pecados y virtudes. Cfr. A. Lindemann, Herrschaft Gottes/Reich Gottes, pp. 212-213. 
12), que los llamó a su reino y a su gloria" (1Tes 2, 10-12). Como también está presente en aquellos que son "juzgados dignos del reino de Dios", eís to kataxiothênai ymâs tês basileías toû Theoû $(2 T e s ~ 1,5)$. Y es que el reino de Dios consiste en "justicia, paz y alegría en el Espíritu Santo" (Rom 14, 17). En todos estos casos, es evidente que Pablo considera el reino de Dios como lo propio de las personas que llevan una vida digna, una conducta moralmente intachable. Pero el pensamiento de Pablo va mucho más lejos en esta línea de lo que he llamado la "conducta intachable". Porque hay tres pasajes de las cartas paulinas en los que se afirma, de manera tajante, que quienes no superan y vencen los vicios, que allí se enumeran, "no heredarán el reino de Dios" (1Cor 6, 9-10; Gal 5, 19-21; Ef 5, 3-5)97. Pablo destaca, ante todo, los vicios relacionados con la sexualidad: formicación, adulterio, afeminamiento, homosexualidad, impureza, libertinaje, conversaciones indecentes, chabacanería. Y relacionados con todo esto, las borracheras y las comilonas. En segundo lugar, los pecados que se refieren a las relaciones con los demás: robo, avaricia, insulto, enernistades, contiendas, envidia, ira, disensiones, rivalidades. Finalmente, Pablo menciona también la idolatría y la magia. Como se ve, una lista abundante de vicios, que degradan a las personas y que, según la leología de Pablo, son incompatibles con el reino de Dios.

Pero ya he dicho que Pablo relaciona el reino de Dios no sólo con la conducta intachable de los cristianos. Además de eso, lo relaciona también con el poder. En este sentido, el Reino de Dios se manifiesta "con fuerza", én dynámei (1Cor 4, 20). De manera que los creyenles son trasladados al reino de su Hijo querido (Col 1,13), porque están "fortalecidos con toda fortaleza, conforme a su poder de gloria", én páse dynámei dynamoúmenoi katà tó krátos tês dóxes (Col 1,11 ). Porque, en definiliva, Pablo concibe la plenilud del reino como una auténtica apoteosis de poder: "Después vendrá el fin, cuando él entregue el reino a Dios Padre, cuando haya anulado a todo principado (pâsan archèn) y toda auloridad (pâsan exousian) y potencia (dynamin), pues él tiene que reinar (basileúein) hasta que ponga todos los enemigos bajo sus pies" (1Cor 15, 24-25). El lenguaje de potestad, triunfo y gloria, no puede ser ni más elocuente ni más fuerte.

La diferencia, por tanto, entre la leología de los sinópticos y la teología de Pablo, en lo que se refiere al reino de Dios, es muy clara. Mientras que, según los evangelios, Jesús presenta el reino de manera que eso nos remite directamente a situaciones y problemas que vive el pueblo (sufrimiento, pobreza, marginación, desprecio y opresión), Pablo piensa en el reino desde sus planteamien-

97. A estos textos hay que añadir la afirmación según la cual "carne y sangre no pueden heredar reino de Dios, ni la corrupeión hereda la incorrupeión" (ICor 15, 50). Aquí sc trata obviamente de que la debilidad humana está incapacitsda para cl reino. 
ros teológicos, que nos remiten a aquellas personas que llevan una vida intachable $\mathrm{o}$ a cuestiones relacionadas con el poder y el triunfo, por más que se trate del poder y el triunfo de Dios. En el fondo, esto nos viene a decir que el mensaje de Jesús ha llegado hasta nosotros en una teología que brota de la vida del pucblo, de cosas de aquí abajo, cosas y situaciones que la gente vive y que la gente ve y palpa, mientras que la teología de Pablo nos habla de otras cuestiones (la justificación por la fe, la libertad con respeclo a la ley, la ética del amor universal y sin diferencias...), que a muchas personas, incluso cultas, no les resulta siempre fácil comprender. Es claro que, a partir de Pablo, la teología empezó a alejarse del pueblo. Es decir, empezó a alejarse de los problemas y las situaciones de la vida, que conciernen e interesan a la gente de la manera más directa posible.

Pero con esto no está dicho todo. Como es sabido, las listas de vicios o pecados, que aparecen en las cartas de Pablo, no se reducen a las que he citado antes en relación al reino de Dios. Además de ésas, hay que recordar también: 1Corintios 5, 10-11; 2Corintios 12, 20-21; Romanos 1, 29-31; 13, 13; Colosenses 3, 5-8; Efesios 4, 3198. Se discute el origen de estos catálogos de vicios, es decir, de dónde tomó Pablo tales listas99. Parece bastante razonable pensar que, de una manera más o menos directa, en esto debieron tener influencia decisiva las ideas de la ética popular de aquel tiempol00. Y sabemos que tales ideas estaban fuertemente condicionadas por el estoicismol01. De manera que, aunque en Romanos 1, 29-31 se acentúan sobre todo las transgresiones sociales 102 , en las listas de vicios, que impiden heredar el reino de Dios, lo que más se destaca son las depravaciones relacionadas con la sexualidad, como he indicado antes 103 .

98. En las cartas pastorales se encuentran también: ITim 1, 9-10; 2Tim 2, 5; Tit 3, 3.

99. Presentación sumaria de las diversas tcorías en: P. S. Zaas, "Cataloges and Context: 1Corinthians 5 and 6", NTS 34, 1988, Pp. 622-629. Información también en W. Schrage, Der erste Brief an die Korinther, EKK VI1/1, Neukirchen, 1991, Pp. 385395; H. Halter, Taufe und Ethos. Paulinische Kriterien für das Proprium christlicher Moral, Frciburg, 1977; S. Wibbing, Die Tugend und Lasterkataloge im N.T. und ihre Traditionsgeschichte unter besonderer Berücksichsigung der Qumrantexte: BZNW 25, Berlin, 1959; E. Kamlah, Die Form der kathalogischen Paränese, Tübingen, 1964. Es conocido, pero ya muy superado, el estudio dc A. Vögtle, Die Tugend und Lasterkataloge im Neuen Testament, Münster, 1936.

100. Cfr. en este sentido, E. Käsemann, An die Römer, Tübingen, 1974, p. 45.

101. Cfr. en este sentido, H. Lietzmann, An die Korinther, 1, Tübingen, 1931, pp. 25-26; H. Conzelmann, Der erste Brief on die Korinther, Göttingen, 1969, pp. 121-122; H. Halter, op. cir., p. 123. Otros autores piensan que el innujo de la filosofie popular helenista le vino a Pablo a través del "judeo-helenismo", concretamente a través de las ideas de Filón de Alejandría. Cfr. E. Käsemann, op. cit., p. 45.

102. Cfr. U. Wilckens, La carta a los Romonos. Rom /-5, Salamanca, 1989, p. 143.

103. Por eso, sin duda, el mismo U. Wilckens señala la inluencia de la ética cstoica en la diatriba de Pablo. Op. cit., p. 143. 
En todo caso, me parece que lo menos importante aquí es precisar, con toda seguridad, de dónde tomó Pablo sus catálogos de vicios. Porque hay un punto que, según creo, resulta determinante a la hora de enjuiciar los posibles influjos que recibió en el tema concreto que aquí estoy tratando. Quiero decir lo siguiente: si algo ha quedado claro, al analizar las ideas del helenismo, es que, desde la República de Platón hasla el De constantia sapientis de Séneca, pasando por los estoicos de Atenas, la figura humana ideal de aquella cultura era el sophós, el "sabio", en contraposición al "plebeyo" o al "villano", el hombre sencillo del pueblo, ignorante y carente de la debida educación o dignidad, cualidades que calificaban a los aristoi, los "selectos". Ahora bien, sabemos que el tema de la sophía (sabiduría) y los sophoi (sabios) ocupó de manera importante las ideas y preocupaciones de Pablolo4. Por supuesto, en esta problemática influyeron los planteamientos del gnosticismo 10s. Pero de este asunto hablaré después. Porque, entre otras cosas, precisamente en la Primera Carta a los Corintios, donde Pablo luvo que afrontar directamente el problema que le planteaban la "sabiduria" y los "sabios", no se habla propiamente de una doctrina gnóstica, tal como se encuentra en los sistemas del siglo IIIOK.

El problema se le presentó a Pablo desde el momento en que, como él mismo dice, se sentía "obligado" o "deudor" (opheilétes) lo mismo con los "sabios" (sophoîs) que con los "ignorantes", anoétois (Rom 1, 14). Ahora bien, en aquel tiempo, hablar de "sabios" no era simplemente referirse a personas de estudios o entendidas en lo que fuera. Ya lo he explicado ampliamente. Y debo insistir en esle punto. Basta leer, en el libro VII de Virae Philosophorum, de Diógenes Laercio, la amplia exposición que hace del "ideal estoico del sabio"107, para darse cuenta de que, cuando se mencionaba la palabra "sabio", se estaba hablando de personas "distinguidas" en todo, por supuesto también en cuanto se refería a la posición social y a la capacidad económica. Por eso no tiene nada de exıraño que los hombres de aquel tiempo pretendieran "ser sabios" (Rom 1, 22). Era una aspiración no sólo inteleclual o religiosa, sino además la lógica pretensión para llegar a ser personas importantes. $Y$ hago caer en la cuenta de que el vocabulario que utiliza Pablo en este contexto de la carta a los

104. Sobre este punto sigue siendo básico el estudio de U. Wilckens, Sophla: TWNT VIl, pp. 496-528, con amplia bibliografía.

105. Cfr. J. Goctzmann, "Sabiduría, necedad," en L. Coenen, E. Beyreuther, H. Bietenhard, Diccionario Teológico del Nuevo Testamento, Vol. IV, p. 126.

106. Cfr. H. Kōster, Introducción al Nuevo Testamento, p. 632. Por eso no parecen aceptables las lesis que se han planteado en esle sentido. Cfr. W. Schmithals, Gnosticism in Corinth, Nashville, 1971.

107. Cfr. H. S. Long, Diogenis Laerii, Visae Philosophorum II, Ox[ord, 1964. Edición española de A. López Eirc, Diógenes Laercio. Los filósofos estoicos, Barcelona, 1990. DL, VIl, pp. 117-126. Op. cit., pp. 187-195. 
romanos es la terminología más característica de la moral estoica. A los que aspiraban a ser "sabios" (sophoi), Dios "los entregó", en primer lugar, a los "deseos" (epithimíais) de su corazón (Rom 1, 24); en segundo lugar, a "pasiones" (pdthe) infames (Rom 1, 26). Ahora bien, como ya expliqué, según los estoicos, la gran dificultad para que el hombre viva en amonía con la razón son las "pasiones"1n8. $Y$, entre las pasiones, la más determinante de todas era el "deseo", categoría fundamental de la que brotaban hasta 31 pasiones concretas 109 . Teniendo en cuenta además que, en el pensamiento estoico, el "deseo" era, por definición, "búsqueda de placer"110. Exactamente lo que les pasó a aquellas mujeres y a aquellos hombres degradados de los que habla Pablo a continuación (Rom 1, 26-27), cuyo extravio fundamental consistió en vivir en contradicción con "la naturaleza" (parà physin), que era la degradación suprema para los estoicos 11 . Pero incluso aquí, Pablo afina hasta el extremo en la utilización del vocabulario estoico. Porque el "deseo" (epirhymia), que experimentaban aquellos presuntos "sabios", era concretamente la orexis, "apetencia" (Rom 1, 27), que era la tendencia interior que estaba permitida a los sophoill2, los hombres selectos, que ignoraban el "placer", pero que vivían en la felicidad: "El fin supremo al que tiende el apetito (orexis) es la felicidad (eudaimonía) de la que participan incluso las bestias privadas de razón"113.

Por lo demás, si los estoicos concedieron una importancia desmesurada al "deseo" (epithymia), no es menor la importancia que Pablo le atribuyó a esa pasión o movimiento interior del ser humano. Hasta el punto de que la raíz del pecado es precisamente eso, el "deseo" (Rom 6, 12). Más aún, el "deseo" es, según Romanos 7, 7-8, la expresión de la "perversión religiosa"114. De ahí, el sentido peyorativo, auténticamente perverso, que tiene la epishymia, en las cartas de Pablo (Rom 1, 24; 6, 12; 7, 7.8; 13, 14; Gal 5, 16.24; Ef 2, 3; 4, 22; Fil 1, 23; Col 3,$5 ; 1$ Tes 4,5$)^{\prime 15}$. En el fondo, se trata de una ética concentrada en la subjetividad, en lo que el individuo "desea" o deja de "descar". Habría que eslar ciego para no darse cuenta de que Pablo coincide en esto con la élica estoica. Una ética que centraba y concentraba el interés del sujeto en sí mismo. Una ética que pudo producir las expresiones sublimes de libertad interior que se

108. SVF I, p. 205; III, p. 377; 391; p. 412; p. 462; p. 479.

109. Cfr. M. Daraki, op. cit., pp. 82-83.

110. SVF III, p. 391 ; p. 386.

111. SVF III, p. 326; p. 8; p. 282. Ciccrón, De finibus, III, p. 73. Cfr. A. Lópcz Eirc, op. cit., p. 163.

112. SVF III, p. 441.

113. SVF III, p. 17.

114. E. Käsemann, An die Römer, p. 184.

115. Cfr. H. Schlier, La carta a los Gálatas, Salamanca, 1975, p. 287. 
encuentran en el $\mathrm{De}$ vita beasa de Séneca116. Pero que también hizo posible que el autor de semejantes afirmaciones fuera preceptor de Nerón. Y que, además, terminara su vida con el suicidio, cortándose las venas por obediencia al tirano.

$\mathrm{Al}$ decir estas cosas, no pretendo afirmar que Pablo fuera un estoico, en el sentido estricto de la palabra. Lo que pretendo es que caigamos en la cuenta de que si, efectivamente, el pensamiento de los esoicos estaba tan profundamente difundido en aquel tiempo y en aquella cultura, no tiene que sorprendernos que no pocas ideas y expresiones de aquella forma de moralidad (tan atrayente en bastantes puntos) dejara su marca y sus huellas en las carlas de un hombre culto, que se había educado precisamente entre gentes que participarían de aquella manera de pensar y de expresarse. Lo sorprendente hubiera sido lo contrario, es decir, que Pablo no hubiera lenido ningún influjo del estoicismo.

Pero es claro que todo esto tuvo sus consecuencias. No sólo en lo que se refiere a la "concentración en la subjetividad" de la moral paulina. Además de eso, tuvo también sus consecuencias en otro punto que me parece aún más determinante. Me refiero a lo siguiente: desde el momento en que Pablo no dudó en conquistar a "sabios" para sus comunidades117, los problemas se le presentaron de manera inevitable. Porque eso llevó consigo que, en las comunidades cristianas, tenían que convivir personas de condición social, de situación económica y de educación muy diversas, incluso contrapuestas. Por eso se ha dicho con razón que "el cristianismo helenístico primitivo no fue ni un movimiento proletario de las clases bajas ni un asunto propio de las clases altas. Lo característico de su estructura social es, más bien, el haber abarcado los diversos estamentos, con su variedad de intereses, de costumbres y de modos de ser"li8. Y la consecuencia fue que "esta mezcla de intereses tan diversos destacó a los cristianos de la masa de las restantes asociaciones privadas, que en general estaban configuradas de la manera más homgénea posible en lo social y en lo económico. Tal situación ocasionó, naturalmente, constantes diferencias entre los cristianos"119.

La prueba más clara de tales diferencias la tenemos en lo que ocurrió en la comunidad de Corinto. Pablo afima que, en esta comunidad, no había ni "mu-

116. Por ejemplo, la absoluta libertad interior: no estar sometido a nada. De vita beata, $\mathrm{XI}, 1$. Si bien esto podía llevar a poseer grandes riquezas, ya que el sujeto no esıaba sometido a ellas. De vita beata, XXIl, 5 .

117. Incluso llega a desear que los cristianos scan "sabios" (sophoús), por supucsto "para lo bueno" (Rom 16, 19).

118. G. Theissen, Estudios de sociologia del cristianismo primitivo, Salamanca, 1985. p. 229.

119. E. A. Judge, Christliche Gruppen in nichichristlicher Gesellschaft. Die Sozialstruktur christlicher Gruppen im ersien Jahrhunderten, Wuppertal, 1964, p. 59. 
chos sabios según la came, ni muchos poderosos, ni muchos de distinguida familia", polloi sophoi katà sárka, où polloi dynatoi, où polloi eúgeneis (1Cor 1 , 26). Una cosa muy clara que se dice aqui es que, si no había muchos "sabios", "poderosos" y "gente disitinguida", es evidente que había algunos que pertenecían a esas tres clases de personas 120 . A mí me parece que el problema no estaba sólo en los individuos de "familia distinguida", los eúgeneîs, como se empeña en probar G. Theissen121. Porque, como ya he dicho tantas veces, en aquel tiempo, "sabios", "poderosos" y "gente distinguida" eran tres expresiones que venían a designar a las mismas personas. Esto se puede afirmar con toda seguridad, no sólo por lo que respecta al pensamiento de los estoicos, sino además, y antes que ellos, era también el punto de vista de Platón.

Pero lo más significativo no es que en la comunidad cristiana de Corinto hubiera algunas personas de alta categoría. Lo determinante es que tales personas eran las más influyentes en la comunidad. Así lo ha demostrado el minucioso estudio de $\mathrm{G}$. Theissen, al analizar las personas y cargos públicos que Pablo menciona en la Primera Carta a los Corintios, las "casas" a las que se refiere, los "servicios" que prestaban tales personas y hasta los viajes que muchos corintios hacían 122. Nada tiene de extraño que en una comunidad así, surgieran problemas y se plantearan conflictos, precisamente por las diferencias entre ricos y pobres. Es lo que ocurrió con motivo de la celebración de la eucaristía (1Cor 11, 1734) ${ }^{123}$, los procesos de cristianos de la ciudad de Corinto entre ellos mismos, probablemente por cuestiones de dinero o asuntos de negocios (1Cor 6, 111) ${ }^{124}$, los problemas que se plantearon entre los "fuertes" y los "débiles", de lo que nos da cuenta el Capílulo 10 y que sociológicamente remite a las diferencias entre los estamentos altos y los más bajos en la comunidadi2s y las tensiones que debieron existir con los esclavos que, naturalmenle, querian liberarse de semejante siluación (1Cor 7, 17-24), pero que se encontraron con la decisión (1Cor 7, 17) de Pablo: "que cada uno siga en el estado en que Dios lo llamó. ¿Te llamó Dios de esclavo? No te importe" (1Cor 7, 20-21).

Está claro, por lo tanto, que las comunidades a las que Pablo dirige sus cartas eran grupos humanos que hoy designaríamos como "interclasistas". Es

120. Asi lo hace notar acertadamente G. Theissen, Estudios de sociología del cristianismo primitivo, p. 192.

121. Op. cil., pp. 191-192.

122. Op. cit., pp. 193-217.

123. Para este punto, cfr. G. Bornkamm, “Eucaristía e Iglesia en san Pablo", en Estudios sobre el Nuevo Testamento, Salamanca, 1983, pp. 103-144.

124. A eso se refiere casi seguro la expresión biotiké. Cfr. F. Preisigke, Wörterbuch der griechischen Papyruskunden I, Berlín, 1925, col. 270. Citado por G. Theisscn, op. cit., p. 219.

125. Cfr. G. Theissen, op. cif., pp. 235-255. 
decir, eran comunidades en las que se reunían personas de estratos sociales muy distintos, desde individuos de las familias más distinguidas hasta las gentes de condición más baja, los "necios", los "débiles", los "plebeyos", los "despreciados" (1Cor 1, 27-28), incluso los "esclavos". Esto quiere decir que los destinatarios que acogieron el mensaje de Pablo fueron muy distintos (sociológicamente) de los que, de hecho, entendieron y acogieron el mensaje de Jesús. Ahora bien, los destinatarios que entienden y acogen un determinado mensaje son la señal más clara y elocuente del contenido de ese mensaje. La cosa es evidente: si los más desgraciados de este mundo comprenden y acogen un discurso, es porque ese discurso transmite algo que responde a la capacidad y a las necesidades de los que carecen de casi todo. En cambio, cuando los destinatarios de una doctrina son personas de educación muy distinta, de posición social muy diversa, de características económicas incluso contrapuestas $y$, por todo eso, que tienen problemas y necesidades muy diferentes, incluso (posiblemente) contradiclorias, si todos ellos comprenden y acogen la doctrina o el mensaje, sin duda alguna semejante doctrina o mensaje no puede ser el mismo que el que entienden y acogen los miserables de la tierra.

Por esto, estoy de acuerdo con los que dicen que la ética de Pablo no pudo ser tan radical como la ética de Jesús. Esloy de acuerdo, por eso, con los que afirman que la predicación de Pablo produjo lo que se ha llamado el "patriarcalismo del amor"126. Se trata del amor que acepla las diferencias sociales como algo dado, pero que las suaviza por medio de la obligación de la consideración y del amor, una obligación impuesta precisamente a los socialmente fuertes, mientras que a los socialmente débiles se les exige subordinación, fidelidad y respe10127. Creo que, efectivamente, esto responde a lo que, de hecho, fue la predicación de Pablo. Pero a mí me parece que no se trata sólo de una cuestión de ética. El problema es más de fondo. Porque toca al contenido mismo del mensaje y no sólo a sus consecuencias prácticas. Por eso, sin duda, el centro del evangelio de Jesús es el reino de Dios, mientras que el centro del evangelio de Pablo ya no lo es. No se trata de una mera diferencia de vocabulario. Se trata de una diferencia de conlenido. Porque el evangelio del reino, según los sinóplicos, es el mensaje que se traduce en salud, vida y felicidad para los enfermos y endemoniados, los pobres, los pecadores y los últimos de este mundo. En sentido distinto, el evangelio que enseña Pablo tiene su centro en el acontecimiento de Cristo, que se traduce y se concreta en la "teología de la justificación", según el texto capital de Romanos 1, 16-17128.

126. Como es sabido, esta expresión provicne de E. Troeltsch, "Die Sozialleheren der christlichen Kirchen und Gruppen", en Ges. Schriften 1, Tübingen, 1923, pp. 67-83.

127. G. Theissen, op. cit., p. 231.

128. G. Eichholz, El evangelio de Pablo. Esbozo de la teología paulina, Salamanca, 1977, p. 77. 
Es claro que en este cambio tan profundo influyó de manera determinante la experiencia personal de Pablo. El no conoció a Jesús. El conoció al Cristo resucilado (1Cor 15, 8-10; cfr. Gal 1, 12; 1Cor 9, 1). Pero no sólo influyó eso. Además de las experiencias estriclamente "religiosas" que tuviera Pablo, la educación que recibió y, sobre todo, la cultura en que se desenvolvió, marcaron inevitablemente el contenido de su mensaje. Y lo marcaron en una doble dirección:

En primer lugar, a partir de Pablo, la teología cristiana empezó a acentuar la subjetividad cuando se trata de explicar la relación y el encuentro de los seres humanos con Dios. Quiero decir: según los evangelios, los seres humanos encontramos a Dios en la medida en que encontramos su reino, es decir, en la medida en que nos ponemos a aliviar el sufrimiento de los que peor lo pasan en la vida. Porque el reino de Dios no es el fin de la historia, sino la transformación de la historia y, por tanto, el empeño y la lucha por cambiar este mundo. Según Pablo, los seres humanos encontramos a Dios en la medida en que cada uno es "justificado" por la fe en Cristo, lo que supone vencer (con la gracia divina) sus "deseos" y "pasiones", para no vivir ya dominado por los "bajos inslintos" y entregarse a la "caridad divina", que trasciende todas las diferencias sociales, culturales, etc. Ahora bien, todo esto significa que, mientras para Jesús, lo determinante es la "objetividad", el cambio de la sociedad, del mundo y de la vida, para Pablo lo delerminante es la "subjetividad", el cambio del propio sujeto en su intimidad más profunda. Se dirá que lo uno y lo otro es necesario. Pero todo depende de dónde se pone el acento y, por tanto, dónde se centra el interés. Jesús centró su interés, ante todo, en el óchlos, el pueblo sencillo y bajo, hasta los más despreciados. Pablo centró su interés en educar y mantener, como pudo, unas comunidades "interclasistas", a las que les enseñó, entre otras cosas, a no tocar el "orden constiluido", sometiéndose a las auloridades civiles (Rom 13,17), aceptando la esclavitud y las diferencias sociales, en definitiva, a "permanecer allí, en donde (el cristiano) fue llamado" (1Cor 7, 24). Y esto significa que "la llamada misma de Dios es la gracia que todo lo trasciende... y que precisamente por eso no obliga al cristiano a cambiar de arriba abajo revolucionariamente la constitución del mundo" 129 .

En segundo lugar, a partir de Pablo, se pone en marcha el proceso de intelectualización de la teología. Por la sencilla razón dc que un mensaje que urge a sus destinatarios a portarse como "sabios", sophoi (Ef 5, 15), tenía que contar, inevitablemente, con lo que las gentes del tiempo entendían cuando se pronunciaba esa palabra. Se trataba, por tanto, de un mensaje para "sabios" o para personas que debían aspirar a comportarse como tales. Pero, es claro, los problemas y el lenguaje que pueden interesar a los "sabios" no son ni pueden

129. G. Eichholz, El evangelio de Pablo, p. 392. Cfr. G. Bornkamn, "Glaube und Vernunft bei Paulus", en Studien zu Antike und Urchristentum, p. 119s. 
ser los problemas y el lenguaje que interesan a los "plebeyos", al démos (que diría Platón) o a los phauloi (según Zenón de Citio y los estoicos). 0 más simplemente, los problemas y el lenguaje del óchlos, según el modo de hablar de los evangelios. Jesús de Nazaret, según la tradición de la fuente $Q$, dijo que su mensaje "se escondía" a los "sabios", mientras que se hacía patente para los que nada tienen que decir en este mundo, nepiois (Mt 11, 25; Lc 10, 21), o sea, los "pobres, sencillos y desclasados" 130 .

Sin duda alguna, el primer teólogo cristiano, san Pablo, introdujo, ya antes de redactarse los evangelios, un giro nuevo en el planteamiento más original de Jesús: al distanciarse del pueblo, la teología inició el largo viaje de la subjetividad y la intelectualización, que tan profundamente marcaron la comprensión de la fe cristiana en los siglos siguientes.

\section{Los "ignorantes" y la "turba despreciable"}

Hoy se suele admitir que Orígenes, el más grande de los pensadores cristianos en el siglo III, fue quien creó "el primer modelo de una teología científica"131. Pero, como se ha dicho (sin duda con bastante fundamento), este primer modelo de una teología más elaborada nació "desde una gran pasión: la de la reconciliación definitiva del cristianismo con el helenismo; mejor: la sublimación del helenismo en el cristianismo. Pero esta cristianización del helenismo debió tener como consecuencia también una helenización del cristianismo"132. Esto es bien sabido. $Y$ por más matices que se puedan y se deban poner en este complejo problema histórico, es un hecho que, además del platonismo y del estoicismo, las corrientes de pensamiento que más influyeron en el cristianismo, desde san Pablo hasta el siglo IV, fueron el gnosticismo y el neoplatonismo, representado especialmente por Plotino. Esto supuesto, la pregunta que aquí se plantea es: ¿cómo incidieron, de hecho, la gnosis y Plotino en el pensamiento cristiano, concretamente desde el punto de vista que aquí se trata de concretar, la relación de la teología con el pueblo?

130. Cfr. U. Luz, Das Evangelium nach Matthäus, EKK 1/2, Zürich, 1990, p. 206.

131. Cfr. H. Küng, Grandes pensadores cristianos, Madrid, 1995, p. 48. En este scntido, Ch. Kannengiesser ha dicho: "Origenes fundó la proxis apropiada para este tipo de teología y fundó la teoría metodológica que ella necesilaba. Cabe preguntarse si la creación de un nuevo paradigma debc traer siempre consigo tanta innovación como la que aportó la crealividad de Orígenes". "Origenes, Auguslin und der Paradigmenwechsel in der Theologie", en H. Küng, D. Tracy (eds.), Theology wohin? Auf dem Weg zu einem neuen Paradigma, Zürich, 1984, p. 154. Amplia bibliografla actualizada sobre Orígenes, en $\mathrm{H}$. Küng, El cristianismo. Esencia e hisforia, Madrid, 1997, p. 832.

132. H. Küng, El cristianismo. Esencia e historia, p. 177. 
Naluralmente, aqui no pretendo exponer, ni siquiera en un breve resumen, lo que fueron el gnosticismo y el neoplatonismo de Plotino. Sólo me interesa destacar lo que estos dos sistemas de pensamiento dijeron (implícitamente o de manera incluso explícita) sobre el "pueblo", la gente sencilla, el vulgo, que es, en definitiva, el asunto concreto que en este trabajo quiero analizar.

En cuanto al gnosticismo, empiezo por recordar algunos conceptos básicos que interesan directamente al tema que aquí estoy tratando. Como es bien sabido, hablar de gnosis es hablar de "conocimiento", no en el sentido de "conocimiento científico" (epistéme), opuesto a "opinión", sino en cuanto "simple conocimiento", opuesto a "ignorancia". Pero, con decir esto, no hemos precisado todavía lo que era en realidad el gnosticismo. Porque no era asunto de cualquier clase de conocimiento, sino que se trataba de un conocimiento estriclamente "reljgioso". En este sentido, se suele entender por "gnosis" el conocimiento de algo divino que trasciende toda fe, una "ciencia" inmediata de la divinidad que se considera como la verdad absoluta133. A partir de este planteamiento básico134, el gnosticismo tomaba como punto de partida el dualismo platónico y se traducía en una hostilidad patente al mundo, a la materia y al cuerpo. Cosa que resulta comprensible desde el momento en que los gnósticos ponían la perfección suprema en el "conocimiento" (gnosis). De tal manera que la expresión más alta de todo este sistema era el "ascenso del alma", el "viaje del alma", que retoma a la unidad divina, precisamente mediante el conocimiento: "El hombre espiritual es redimido por medio del conocimiento... La perfecta redención consiste en el conocimiento mismo de la grandeza indecible" 135 .

Ahora bien, en la medida en que los gnósticos ponían la salvación y la perfección en el "conocimiento", inevitablemente el gnosticismo se constiluía, desde el punto de vista sociológico, en un "gnupo minoritario elitista". Por la senci-

133. Cfr. A. Piñero y J. Montserrat, en la Introducción general a sexıos gnósticos. Biblioteca de Nag Hammadi 1, Madrid, 1997, p. 33. Una introducción bibliográfica suficiente, en esla obra, pp. 115-117. Bibliografía más amplia, en H. Küng, El crissianismo. Esencia e historia, pp. 828-829. Para el gnosticismo de los siglos II y III, que es el que más directamente nos interesa aqui, es fundamental la obra de $\mathbf{A}$. Otbe, Introducción a la teologla de los siglos II y III, Roma-Salamanca, 1988.

134. En el núcleo esencial del gnosticismo está "la creencia en la presencia en el hombre de una chispa o centella, que proviene del ámbito de lo divino y que en este mundo se halla sometida al destino, al nacimiento y a la muerte. Esta chispa divina debe ser despertada por la contrapartida divina del yo humano para ser finalmente reintegrada al lugar de donde procede". A. Piñero, J. Montscrral, op. cir., pp. 35-36. Esta es la conclusión que, como tesis, presentaron los expertos reunidos en el coloquio de Messina en 1966. Cfr. U. Bianchi (ed.), Le Origini dello gnosticismo. Colloquio di Messina, 13-18 aprile 1966, Leiden, 1966, pp. XX-XXI; K. Rudolph (ed.), Die Gnosis und Gnosticismus, Darmstadı, 1975, pp. 65-66.

135. Ireneo, Adv. Hoer. I, 21, 4. 
lla razón de que "poseer un conocimiento superior y reservado" es cosa que no está al alcance de todo el mundo. Más aún, si "gnóstico", en sentido estricto, era lo mismo que "miembro de un grupo elitista que posee un conocimiento religioso exclusivo" 136 , lo lógico es pensar que eso tenía que ser privilegio de personas selectas. Es decir, si algo había claro en el gnosticismo, es que distinguía, con vigor y precisión, entre los "conocedores" y los "ignorantes"137. De ahí que, como se ha dicho con razón, nomalmente los gnósticos eran gente ilustrada y no debían pertenecer a las clases más bajas, sino a las medias y superiores del mundo antiguo. Esto se deduce obviamente del hecho de que la mayoría de las confesiones gnósticas basaban sus doctrinas en difíciles interprelaciones alegóricas de textos sagrados. $Y$ es claro que para eso se requiere una cierta formación intelectual no fácilmente accesible a los pobres 138 . En este sentido, es evidente que cuando uno intenta enterarse, pongo por caso, de las complicadas especulaciones que hacían los valentinianos, desde la "primera secuencia" (el Desdoblamiento del Pleroma) hasta la "sexta secuencia" (la emisión del Salvador) ${ }^{139}$, resulta poco menos que imposible imaginarse a gente ignorante y pobre elevándose a la difícil altura de semejantes elucubraciones. Como tampoco cabe en cabeza humana que gentes sin una elevada formación intelectual pudieran entender los documentos setionos de Nag Hammadi, que representan un verdadero puente exegético entre la especulación judía helenista y la primera teología trinitaria cristiana ${ }^{40 .}$

Así, pues, queda claro que el gnosticismo, por más matices que sea necesario ponerle a esta compleja y complicada forma de pensamiento, destacaba claramente tres cosas: la supremacía absoluta del "conocimiento" para cualquier pretensión de acercamiento a Dios; la prevalencia, por tanto, de la "subjetividad", en cuanto que la práctica de la salvación consistía, según los gnósticos, en un modo de vida que llevaba al espiritu a liberarse de la materia, hasta el punto de que condenaban la sexualidad, el matrimonio y la procreación, se olvidaban de los negocios, de la vida ciudadana y de la políticalal y era, por tanto, una forma

136. A. Piñero, J. Montserrat, op. cit., p. 34.

137. A. Piñero, J. Montserrat, op. cit., p. 34.

138. A. Piñero, J. Montserrat, op. cit., p. 85.

139. Según el Tratodo trijartito, el Salvador es un fruto común de los eones (86, 15-26; 87, 6). En el Evangelio de la Verdad la figura del Salvador aparece tras la figura de Jesús (cfr. 20, 10ss). Según Ireneo, "los sucesos que describen fuera del Pleroma son los siguientes: la Intención -a la que, asimismo, llaman Achamos- de la Sabiduría superior, una vez separada del Pleroma, entró en ebullición por necesidad en regiones de sombra y vacío, porque salió de la luz y del Pleroma informe y sin figura, a manera de aborlo, por no haber comprendido nada". Adv. Haer. I, 4, 1.

140. Cfr. A. Orbe, Estudios valentinianos, Vol. I, Roma, 1955, Intr.

141. De ahí que la llamada "postura libertina" no sc dio práclicamente entre los gnósticos. Con todo, algunos autores cristianos critican los excesos que, a veces, se dieron. Por ejemplo, Epifanio, Panarion 26, 4, 3-8; Ireneo, Adv. Haer. I, 13, 3 ss. 
de entender y vivir la religión que no estaba al alcance del pueblo, de los ignorantes y de los pobres.

Por lo que se refiere al neoplatonismo, sabemos que Plotino entiende la "realidad" como un proceso incesante, como un desartollo de naturaleza espiritual, que acontece "fuera del espacio y del tiempo", y que se despliega en diferentes "etapas"142. Las etapas de este despliegue son lo Uno, la inteligencia y el alma. De manera que, por debajo del alma, se halla la materia, que es el último escalón y el límite de la realidad, pura potencialidad informe, no ser, sustrato y receptáculo de formas, impasible143. Lo cual es cierto hasta el punto de que, como explica Plotino en la Enéada II, 4, 8-10, la materia no es cuerpo ni tiene magnitud. Y, además, es aprehendida por un razonamiento bastardo, fundado en una falsedad144. Hasta ese extremo llega el intelectualismo de Plotino o, si se quiere, el "pensamiento puro"145, que le caracteriza.

Ahora bien, a partir de este planteamiento básico, Plotino afirma que es a través del alma como el ser humano debe integrarse en "lo inteligible", para lograr así la conversión hacia "lo Uno", que es la "potencia de todos los seres" y "fuente que no tiene otro principio que ella misma"146. Para ello, el alma debe huir, regresar a la patria, al origen, para recuperar su estado "divino"147. Pero este recorrido del alma no es otra cosa que una progresiva simplificación. De manera que su mela no está fuera de ella, sino que, como se ha dicho, "la encuentra cuando revierte hacia su propia interioridad y hace coincidir su propio centro con el centro del universo"148.

Hasła aquí se comprende fácilmente que el ideal de Plotino es un proyecto de interioridad y, por tanto, de subjetividad llevada hasta el extremo. Pero no es esto sólo lo que me interesa destacar. Lo importante es comprender en qué pone Plotino esta interioridad. Porque no se Irata simplemente de conocer, de saber. Es algo mucho más profundo. El acceso a "lo Uno", su visión, lo alcanza, no ya la "inteligencia sabia", sino la "inteligencia amante", "embriagada de néctar", que llega así a su plenitud dichosa 149. Pero, ¿cómo? La aprehensión defínitiva

142. Cfr. En. V, 2, 2. Para una breve introducción al pensamiento de Plotino, cfr. M. I. Santa Cruz, "Plotino y el neoplatonismo", en C. García Gual, Historia de la filosofla antigua, Madrid, 1997, pp. 339-361, con bibliografía en pp. 358-361. Bibliografía más completa, en E. Borrego, Cuestiones plotinianas, Granada, 1994, Pp. 215224.

143. En. III, $6,7$.

144. En. II, 4, 10.

145. Cfr. E. Borrego, op. cit., pp. 39-40.

146. En III, 8, 10.

147. En. V, 1, 5 .

148. M. I. Santa Cruz, op. cir., p. 356.

149. En. VI, 7, 35. 
del sublime ideal se alcanza por la propia inteligencia. Porque la inteligencia tiene la capacidad de conocer ese principio definitivo y último. Lo que se consigue en un intento supremo de concentración, cuando se llega al punto más alto posible de la actividad racional. Y es entonces cuando "se produce, sin que se sepa cómo, la presencia, la aparición, la visión, el contacto, el máximo acercamiento, el éxtasis interior, la coincidencia del centro con el centro, la simplificación, la unificación, la supresión de la alteridad, el tomarse una mismo luz la que es vista y la que ve"150. En definitiva, la contemplación viene a ser la unificación en la búsqueda del Bien supremo1sı.

Como resulta fácil comprender, todo esto significa que, en Plotino, la filosofía desemboca en la más alta mística. Pero no sólo eso. En última instancia, la teoría del "retomo" del alma, hasta la unificación suprema, "vino a constituirse en paradigma de la ascesis crisliana"152. Es decir, el modelo supremo de la espirilualidad.

Esto es así. Y sin embargo, uno se lleva la gran sorpresa cuando encuentra en Plotino, junto a semejante elevación mística, el desprecio más profundo (una vez más) hacia el pueblo, la gente sencilla y trabajadora, que no entiende, ni puede entender, de elevaciones místicas o éxtasis supremos. No exagero. En la Enéada 11, 9, 9, Plotino dice que hay tres clases de hombres: "la de los virtuosos y la de la mayoría de los hombres; la de los virtuosos aspira al ideal supremo, a lo alto; la de los hombres corrientes es a su vez de dos clases: la de quien, acordándose de la virtud, tiene alguna parte en el bien, y la de la turba despreciable, que es algo así como el manufacturero de los productos que necesitan los más dignos"153. O sea, los trabajadores manuales (y no digamos los pobres y miserables de la sociedad) no pasan de ser el "vulgo vil", la gente que no tiene más destino que trabajar para los "virtuosos", los únicos verdaderamente dignos

150. M. I. Santa Cruz, op. cit., p. 357, que remilc a R. Annou, Le désir de Dieu dans la philosophie de Plotin, Roma, 1967, pp. 235ss; J. Rist, Plotinus. The Road to Reality, Cambridge, 1967, pp. 213-230.

151. En. III, 8, 8.

152. E. Borrcgo, op. cif., p. 75. De hecho, como es bicn sabido, de los diversos influjos del platonismo sobre el cristianismo, sin duda alguna, el más determinante, para la vida de los cristianos, fue cl platonismo en la concepción de la vida interior. $C f r$. $R$. Arnou, "Platonisme des Pc̀res", en Vacant-Mangenot, Dictionnaire de Théologie Catholique, X1V/2, Pp. 2362-2372.

153. Es posible que Plotino tralc de oponer esta división tripartita a la también tripartita de los gnósticos "valentinianos", basada en la existencia de tres razas originarias o "castas": la de los pneumáticos (representada por Set) está salvada por naluraleza; la de los psíquicos (represcntada por Abcl) sc salva o se picrde scgún su propia libertad; la de los hílicos (representada por Caín) está perdida por naturaleza. Cfr. Irenco, Adv. Haer. I, 7, 5. Cfr. J. Igal, Porfirio, Vida de Plotino. Plotino, Enéada., I-II, Madrid, 1992, p. 511 , nota 85. 
que hay en esta vida. Y para que no quede duda en este asunto, el mismo Plotino añade casi a renglón seguido: "Y si el mundo es una palestra de vencedores y vencidos, ino es verdad que aun por este concepto es una obra sin tacha?"154. Por lo visto, al gran maestro de mística y contemplación, que fue Plotino, no le preocupaba demasiado que este mundo fuera un verdadero campo de batalla155, en el que hay "vencedores y vencidos".

\section{La teologfa: un "saber para selectos"}

Seguramente, a muchos creyentes (incluso a algunos teólogos) les liene que resultar difícil hacerse una idea, más o menos aproximada, de la confusa mezcolanza de grupos, clases sociales y creencias que configuraban al cristianismo de los siglos primero al cuarto. Empezando por lo más sencillo, desde el punto de visto socioeconómico, sabemos que en las comunidades cristianas se reunían gentes de estratos sociales y económicos, no sólo distintos, sino incluso contrapuestos. Como ya expliqué antes, esto empezó a ocurrir en tiempo de san Pablo, concretamente en la comunidad de Corinto, que es la que mejor conocemos entre las comunidades del siglo primero. En el siglo II Clemente de Alejandría les echa en cara a los cristianos ricos que "pretenden tener más que los demás". Y, por tanto, "el argumento ese de 'tengo y me sobra, ¿por qué no he de disfntarlo?', no es humano ni comunitario"156. Este reproche indica obviamente que en la comunidad cristiana habia ricos. Y, por cierto, ricos que sin duda abusaban de su riqueza. En el siglo III, Orígenes se ve obligado a rebatir a Celso porque, entre olras cosas, despreciaba a los cristianos a causa de su baja condición social. Eso era falso, ya que en las comunidades había también sabios y personas influyentes 157 . Pero, sin duda alguna, el documento más elocuente sobre las divisiones y tensiones que había entre los cristianos en el siglo III es la Didaskalía. La idea en la que más insiste el didascalista es que los obispos tenían que mirar, con extremo cuidado y escrupulosidad, quiénes eran los que llevaban limosnas (en la celebración eucarística) para los pobres de la comunidad 158. Y a continuación presenta una lista de personas de las que no se podían recibir limosnas: los ricos que trataban mal a sus criados, los que oprimían a los pobres, los comerciantes injuslos, los que traficaban con condenas legales, etc. ${ }^{159}$. Evidentemente, si en las comunidades se dieron tales normas, es porque

154. En. II, 9, 9.

155. Así exactamentc entiende Plotino la imagen de la "palestra". En. Ill, 2, 8.

156. Ped. 2, 12. Citado por J. 1. González Faus, Vicarios de Cristo. Los pobres en la teologla y espiritualidad cristianas, Madrid, 1991, p. 14.

157. Conir. Cels. III, 48.

158. Esta norma se repile una y olra vez. Didask. II, 17, 1; 17, 2; 17, 3; 17, 6; 22, 1; 24, 3. Y la razón de csto es que la Didaskalía considera al obispo como el administrador de los bienes de la comunidad. Didask. II, 31, 1-2; 33, 1-3; 24, 6.

159. Didask. IV, 6, 1-5. 
entre los cristianos había ricos y traficantes que cometían atropellos. Con el agravante de que, según dice el didascalista, debía ocurrir con frecuencia que tales individuos eran los únicos que daban el dinero necesario para las obras sociales de la comunidad160. Es verdad que la Didaskalía prohibe severamente recibir ayudas de esa gente, hasta el extremo de afimar que es "preferible morirse de hambre antes que recibir nada de los malvados"161. Lo cual indica un alto grado de coherencia. Pero también es cierto que en ningún momento dice el didascalista que a los ricos y traficantes injustos se les excluya de la comunidad. Por lo demás, este tipo de problemas debió abundar en las iglesias de los siglos III y IV, ya que la misma norma se repite en las Constituciones Apostólicas, que reproducen casi al pie de la letra las nomas de la Didaskalía, y en los Statuta ecclesiae antigua 162, que estuvieron en vigor en bastantes iglesias de occidente, por lo menos hasta el siglo $\mathrm{V}$.

Pero si las cosas fueron difíciles por lo que se refiere al "interclasismo" socioeconómico, mucho más complicada resultó la situación propiamente religiosa. Sobre todo por la confusión de ideas y corrientes de pensamiento que se vinieron a mezclar, hasta el punto de no saber, muchas veces, hasta dónde llegaba lo cristiano y dónde empezaban otras teorías, saberes o creencias. Baste recordar que, en aquellos siglos, se propagaban y se aceptaban, por todos los rincones del imperio, el platonismo, el estoicismo, el gnosticismo y, a partir del siglo III, las ideas de Plotino. Lo que pasa es que nosotros ahora, si, por ejemplo, nos ponemos a leer el Adversus Haereses de Ireneo, podernos pensar que todo estaba claro: hasta aquí, los errores de los gnósticos; y desde aquí, la verdadera doctrina. O si estudiamos la excelente Introducción a la teología de los siglos II y III, de A. Orbe, vemos perfectamente delimitado lo que decían los "heterodoxos" y lo que defendían los "eclesiásticos". Pero me pregunto si el pueblo creyente, la gente de las comunidades, tenía las cosas tan claras y bien delimitadas. Piénsese, por ejemplo, en que, además de los escritos canónicos del Nuevo Testamento, circulaban otros escritos presuntamente cristianos de pura ley, por ejemplo, el Evangelio de Tomás, el Evangelio de Felipe, el Evangelio de la Verdad, el Evangelio de los egipcios, el Apócrifo de Juan, en su versión breve y en su versión larga, el Evangelio de María 163. Esto, si nos limitamos a la literatura de origen gnóstico.

160. Didask. IV, 8,$3 ; 8,4 ; 9,1-2$.

161. Didask. IV, 8, 2.

162. En el canon 69. Cfr. Ch. Munier, Les Statuta ecclesiae antiqua, París, 1960, p. 91.

163. Esto, por lo que respecta a los trece códices de la biblioleca de Nag Hammadi. Cfr. A. Piñero, J. Montserrat, F. García Bazán, Textos gnósticos. Biblioteca de Nag Hammadi, pp. 23-27. 
Pero la situación era mucho más compleja. Para hacerse una idea de cómo estaban las cosas, voy a poner un ejemplo que me parece elocuente. Me refiero a Cipriano de Cartago, que dedicó un tratado completo a describir su conversión y su bautismo, pero cuenta todo esto de tal manera que, en todo el tratado, no aparece ni una sola vez la palabra Jesús, ni la palabra Cristo, ni la palabra evangelio, ni Iglesia, ni reino de Dios, ni comunidad cristiana. O sea, en la conversión de este hombre, que después fue considerado como el papa de Africal64, no parece que tuviera sitio alguno la experiencia de Jesús y su evangelio. Por lo menos, de eso no dice ni palabra. Entonces, ¿a qué o a quién se convirtió este hombre? Por lo que él mismo dice, en el tratado Ad Donatum, está fuera de duda que el verdadero motor, en la conversión de Cipriano, fue el ideal de la filosofía estoical65. Y si esto es lo que sucedió en el caso de san Cipriano, uno de los testigos más cualificados de la tradición cristiana en el siglo III, me parece que hay motivos sobrados para preguntarse qué grado de confusión tuvo que darse entre las gentes que, en aquel tiempo, entraron en tropel en las comunidades cristianas. Porque, como es bien sabido, desde el año 203, cuando Orígenes empezó su labor docente en Alejandría, hasta el 248, cuando publicó su Contra Celsum, los pueblos del imperio vivieron una época de inseguridad y miseria creciente, mientras que la Iglesia pasó por una etapa de libertad relativa, sin persecuciones, lo que ayudó lógicamente a que se produjera un intenso crecimiento numéricol66. Ahora bien, es lógico pensar que muchas de aquellas personas venian a las iglesias cristianas buscando lo mismo, poco más o menos, que buscó Cipriano. Y, además, venían con sus ideas platónicas, estoicas, gnósticas. A cualquiera se le ocurre pensar que tuvo que ser práclicamente imposible evitar las interferencias entre unas creencias y otras. Y, con frecuencia, no sólo las interferencias, sino además las mezclas y hasta la confusión. Recientemente, un buen especialista en Plotino ha escrito: "No se discule, por supuesto, el hecho cultural consumado de la interpretación del Platonismo que nos ofrecieron pen-

164. Así aparece, repetidas veces, en las carlas del mismo Cipriano: Epist. XXIII; XXX; XXXI; XXXVI. Cfr. Ch. Saumagne, Saint Cyprien de Carthage "Pape d'Afrique", Paris, 1975.

165. En efeclo, por lo que afirma el mismo Cipriano, su conversión fue el logro de la seguridad (Ad Donat. 4) firme y estable (op. cir., p. 13) que lleva al puerto de la salvación (op. cir., p. 14). Y, sobre todo, consiguió el idcal de las virtudes (viła virtutum. Op. cir., p. 6). Ahora bien, sabemos que en esto consistia el ideal estoico. Así lo demostró ya H. Koch, Cyprianische Untersuchungen, Bonn, 1926, pp. 286313. Más recientemente ha analizado los paralelismos de Cipriano con Séncca G. Barbero, "Seneca e la conversione di san Cipriano", Rivista di Studi Classici 10, 1962, pp. 16-23. En el mismo sentido, M. Pohlenz, Die Stoa. Geschichte einer geistigen Bewegung, Gōttingen, 1947, p. 357.

166. Así lo ha demosirado E. R. Dodds, Paganos y cristionos en una época de angustio, Madrid, 1975, p. 141. 
sadores como Filón de Alejandría, Orígenes, Gregorio de Nisa o san Agustín. Sólo se discute su significación. Por mi parte, pienso que demostraron la validez del esquema platónico para una mística religiosa hasta el punto de encontrarse ellos mismos envueltos en tal esquema"167.

Ahora bien, si los primeros teólogos cristianos, los grandes teólogos de los siglos III y IV, asimilaron los esquemas de pensamiento que impregnaron el mundo helenista, $y$ hasta se vieron envueltos en tales esquemas, la pregunta que me planteo es: ¿con quién estuvieron más de acuerdo aquellos teólogos: con la cercania de Jesús al pueblo o con el desprecio de las filosofías de entonces hacia el pueblo? No hablo de "coincidencia" entre los teólogos y aquellas filosofias. Porque sabemos que no existió tal coincidencia. Hablo del "mayor o menor acuerdo", es decir, me pregunlo si aquellos primeros pensadores de la fe cristiana estuvieron más próximos a Jesús, al hablar del pueblo, o por el contrario, si sintonizaron más con el platonismo o el gnoslicismo al referirse a ese mismo asunto.

Al responder a esta cuestión, debo recordar ante todo un hecho que ya hizo notar J. Lebreton: los apologistas de los siglos Il y III (Taciano, Atenágoras, Minucio Felix, Tertuliano), preocupados por mostrar que la verdadera filosofía era la doctrina de los crislianos, pusieron especialmente de relieve lo que, en las creencias cristianas, respondía a las curiosidades metafísicas de sus lectores, los eternos problemas sobre Dios, el origen de las cosas y del mundo, la naturaleza del alma, etc. Pero, es claro, una preocupación de este tipo, centrada sobre todo en cuestiones de tipo filosófico, orientó la especulación de estos escritores hacia el público que andaba preocupado por tales asuntos. Y así ocurrió que, inevitablemente, aquellos primeros teólogos se alejaron de la masa de los simples y humildes creyentes, los pobres ciudadanos que no entendían de filosofías y que pronto se dieron cuenta de que aquellos tratados apologéticos no estaban escritos para ellos 168. Esta tendencia, esta orientación especulativa, llegó a tal punto que el mismo Tertuliano, en un texto bien conocido, no dudó en quejarse de los que tanto filosofaban: "¿Qué hay de común entre Atenas y Jerusalén?, ¿entre la Academia y la Iglesia?... ; Tanto peor para los que han puesto de moda un cristianismo estoico, platónico, dialéctico! Nosolros no tenemos ninguna otra necesidad después de haber conocido a Jesucristo, ni de investigación alguna después del evangelio"169.

167. E. Borrego, Cuestiones plotinianas, p. 16. Dcl mismo autor: El pecado de origen en Plotino y Gregorio de Nisa, Granada, Facultad dc Teología, 1991; "Mística y filosolía en Plotino", Pensamiento 49, 1993, pp. 353-369.

168. J. Lebreton, "Le désaccord de la foi populaire et de la théologic savante dans l'Église chrétienne du IIl siècle", Revue d'Histoire Ecclesiastique 19, 1923, pp. $482-483$.

169. De Praescipt. VIJ, 9-13. 
Este texto de Tertuliano nos pone en la pista de un problema que debió ser fuerte en aquel tiempo y en aquella cultura, tanto en occidente como, sobre todo, en oriente. Por eso, nada tiene de extraño que Clemente de Alejandría denunciase el miedo de los cristianos a la filosofía: "Parece que la mayoría de los que se llaman cristianos se comportan como los compañeros de Ulises: se acercan a la cultura (logos) como gente burda que ha de pasar no sólo junto a las sirenas, sino junto a su ritmo y su melodía. Han tenido que taponarse los oídos con ignorancia, porque saben que si llegasen a escuchar una vez las lecciones de los griegos, no serían ya capaces de volver a su casa"170. Más aún, Tertuliano, que como he dicho hace un momento se quejaba de las especulaciones filosóficas, tuvo también palabras muy duras a la hora de referirse al pueblo sencillo: "Los simples, por no hablar de los imprudentes y los ignorantes, $-\mathrm{y}$ esas gentes forman siempre la gran masa de los creyentes-, viendo que la regla de fe nos hace pasar del politeísmo pagano a un Dios único y verdadero, no comprenden que es necesario creer en efecto en un Dios único"171. Las expresiones, que utiliza aquI Tertuliano al referirse a la gente sencilla, son francamente desagradables: simplices, imprudentes, idiotae. Y es que los teólogos de aquel tiempo se preocupaban ya de problemas que el pueblo no entendía172. Lo que vino a provocar la división entre dos grupos de cristianos: unos, celosos de su saber, se creían los mejores; los otros, gentes sencillas, se inquietaban de las especulaciones que no alcanzaban a entender 173.

Pero, sin duda alguna, donde este estado de cosas vino a complicarse más fue en oriente, entre otras razones porque alli, el gnoslicismo (con sus altísimas especulaciones) luvo más implantación174 y, por tanto, resultó más decisivo en

170. Strom. VI, 11, 89, 1. Cfr. J. Vives, Los Padres de la Iglesia. Textos doctrinales del cristianismo desde los origenes hasia san Agustín, Barcelona, 1971, p. 207.

171. Adv. Prax. 3.

172. Me refiero concretamente al complicado problema de la oikonomia, que aparece ya en el lexto antes citado del Adversus Praxeam de Tertuliano. De ahi que, por ejemplo, Hipólito de Roma se enfrente a Ceferino y a Calixto, a los que considera "inteligencias vulgares" precisamente porque no querían lanzarse por el camino de la nueva ciencia, que era su concepción "económica" de Dios. Cfr. A. Harnack, Dogmengeschichre, I, p. 740. Citado por J. Lebreton, op. cir., p. 489. Por lo demús, como ya se hizo notar en el siglo XIX, la problemática del lenguaje teológico provenía de la línea trazada por san Pablo. Cfr. W. Gass, "Das patristische Worl oikonomía", Zeitschriff für wissenschaftliche Theologie 17, 1874, Pp. 465-504. Más recientemente, en el mismo scntido, A. d'Alćs, "Lc mol Oikonomia", Revue des études grecques 32, 1919, pp. 8-9. Cfr. J. Lebretun, op. cit., pp. 488-489.

173. Cfr. J. Lebreton, op. cir., pp. 490-491, que aporta más documentación de aquel tiempo en este sentido.

174. No se olvide que la biblioleca de Nag Hammadi se encontró en el alto Egiplo y que sus traduclores probablemente fueron monjes alejandrinos, lo que indica la influen- 
los planteamientos de la teología. En esta dirección se destacan, sobre todo, Clemente y Orígenes. Ya el maestro de Clemente, Panteno, expresa la oposición que había entre los que se resistían a "los misterios de la gnosis" y los que "se habituaban a ella", que por eso exultaban de gozol75. Pero esta "gnosis" es algo tan precioso y tan alto que está representada, en este mundo, como un secreto trasmitido por los presbíteros y confiado sólo a los que son dignos 176. Y es claro, a partir de semejantes enseñanzas, que Clemente no dudó en dividir a la humanidad en dos razas, una predestinada a un cristianismo inferior, la otra a la "gnosis"177. De manera que, en los Stromata VI y VIl, explica cómo, cuando abandonó Alejandría, se entregó a una vida exenta de pasiones, dedicado a la contemplación perpetua, elevado por encima de la humanidad. Vivía, dice Clemente, aquella "gnosis, venida de los apóstoles y transmitida oralmente, que había llegado a un reducido número de hombres"178. Es evidente que el "elitismo" que manifiestan estos texlos es algo que no estaba, ni podía estar, al alcance de la gente sencilla. La teología ya esiaba decididamente orientada hacia los "selectos". Clemente no lo oculta precisamente al describir quién era para él el creyente ideal: el gnóstico posee la ciencia y la virtud perfeclas, lo sabe todo, lo alcanza todo, lo comprende todo; cada una de sus acciones es la rectitud misma (katórthoma) 179; es apóstol, es sacerdote, constituye no sólo la elite, sino incluso la verdadera jerarquía de la Iglesial80. Parece que ya más que esto nada se podía decir.

Y, sin embargo, se dijo. Porque Orígenes llegó más lejos. En efecto, este autor que fue "quien creó, quien encamó incluso, el primer modelo de una teología científica"।81, distingue claramente dos clases de creyentes: los cristianos vulgares, que no alcanzan más allá de lo que son cosas bajas; y los espirituales, que son los que contemplan la gloria divina. En el primer grupo, están los que "sólo conocen a Jesucristo, y Jesucristo crucificado, estimando que el

cia que tuvo el gnosticismo entre los cristianos de Alejandría en el siglo III. Cfr. K. W. Trüger, "Einfürung. Zum gegenwärtigen Stand der Gnosis-und Nag-Hammadi Forschung", en Id. (ed.) Alıes Testament-Frühjudentum-Gnosis. Neue Studien zu "Gnosis und Bibel", Gütersloh, 1980, p. 29.

175. Eclog. 35. Cfr. W. Bousset, Jüdisch-christlicher Schulbetrieb in Alexandria und Rom, Göttingen, 1915, pp. 155-217.

176. Eclog. 27.

177. Es la idea que desarrolla en Sirom. VI, 9, 78, 4.

178. Strom. Vl, $7,61,1$.

179. Sirom. VI, 65-68; 70-79; 106-111; VII, 55-59. Cfr. J. Lebreton, op. cit., p. 499.

180. Sirom. Vl, 106-107.

181. H. Küng, Grandes pensadores cristionos, p. 48. De él ya se había dicho mucho antes que ha sido "uno de los pensadores más originales de lodos los tiempos". J. Quasten, Pairologia, 1, Madrid, 1961, p. 338. 
Logos hecho came es el todo del Logos; son los que conocen solamente a Cristo según la came: tal es la muchedumbre de los que son considerados como creyentes". En el segundo grupo, que obviamente son los mejores, los seleclos, están los que "participan del Logos que existía desde el principio, que estaba junto a Dios, el Logos de Dios"182. Sin duda, esta curiosa clasificación tiene que resultar extraña a muchas personas en la actualidad. Para Orígenes era lo más natural del mundo. Porque, según el gran maestro de la escuela de Alejandría, la fe simple tiene por objeto central a Jesucristo crucificado, lo que es, por supuesto, un conocimiento saludable; pero es también un conocimiento elemental, adaptado a los que son demasiado débiles para elevarse más alto183. Pero entre los creyentes existe un grado superior: "los espíritus de elite que se ejercitan en filosofar sobre nuestra doctrina"184. De ahí que, para Orígenes, el evangelio, que creen comprender las gentes del vulgo, enseña las sombras de los misterios de Cristo... Por eso es necesario que el cristianismo sea espiritual y corporal; y cuando es preciso anunciar el evangelio corporal y decir que no se conoce entre los camales nada más que a Jesucristo y Jesucristo crucificado, se debe hacer así. Pero cuando se encuentra a los perfectos por el Espíritu, que llevan en sí los frutos de la sabiduría celeste, se les debe comunicar el discurso que se eleva desde la encarnación hasta lo que está junto al mismo Dios'85.

Todo esto quiere decir que, según Orígenes, hay en el cristianismo dos clases de enseñanzas: la que se debe presentar al pueblo, a la masa de la gente vulgar; y la que está reservada a los perfectos. La primera es la que se nos presenta como la leche que toman los niños; la segunda es el alimento sólido que nutre a los selectos 186 .

La fuente de donde Orígenes tomó estas ideas es bien conocida. Se trata, en primer lugar, del platonismo. Y, a partir del siglo II, del gnosticismo, que ejerció

182. In Joann. II, 3, 27-31. El mismo planteamiento se repite en el comentario al cvangelio de Mateo. In Masth. XII, 30. Ha esludiado esta clasificación y el problema que implica J. Lebreton, "Les degrés de la connaissance religieuse d'après Origène", Rech.Sc.Rél. 12, 1922, pp. 265-296.

183. Esta es la idea que desarrolla en Contr. Cels. I, 9 y 13.

184. Contr. Cels lil, 79.

185. In Joann. I, 7, 43.

186. La primera es la que nos presenta la carta a los corintios: El quia lacte adhuc indigebant, ea discunt quae discere parvuli solent. La segunda es propia de los efesios: quod solidus cibus mysricus iniellecius. In Ezech, hom. VII, 10. Un planteamiento distinto se encuentra en el comentario al evangelio de Mateo. In Malth. XII, 19. De todas maneras, es insistente en Orígenes la asociación que hace entre el cristianismo elemental, propio del pueblo vulgar y la fe en Cristo crucificado. $C f r$. In Joann. I, 7, 43; 1, 9, 58; 1, 18, 107; II, 3, 29; II, 3, 33; XIX, 11, 68; Contr. Cels. II, 66; Peri Archon IV, 4, 31. Cfr. J. Lebreton, Les degrés de la connaissance religieuse d'après Origène, p. 279. 
una influencia determinante en Alejandría. Sabemos que alli fue donde nació el helenismo. Allí vivió Filón, que intentó combinar las enseñanzas del Antiguo Testamento con las especulaciones griegas. Por eso, como explicó ya $\mathrm{J}$. Quasten, cuando a fines del siglo I el cristianismo se estableció en esla ciudad, entró en contacto con todos estos elementos. Como consecuencia, se suscitó un vivo interés por los problemas de tipo teórico. Y por eso, el medio ambiente en el que se desarrolló la escuela teológica de Alejandría le imprimió sus rasgos característicos: marcado interés por la investigación metafísica del contenido de la fe, preferencia por la filosofía de Platón y la interpretación alegórica de la Escritural 187 . En cuanto al gnosticismo, no se piense ingenuamente que, para los cristianos de aquellos tiempos, fue una burda herejía y nada más que eso. Hoy está fuera de duda que el cristianismo gnóstico se constituyó, no como "reacción contra, sino como estadio superior sobre el cristianismo común"188. Ahora bien, sabiendo como sabemos lo que en aquella sociedad representó el gnosticismo, pasó lo que tenía que pasar: los cristianos se dividieron en dos grupos. De una parte, la elite de los privilegiados, que se tenían por los perfectos, los elegidos, la clase superior en la Iglesia. De la otra parte, la masa de la gente ignorante, el pueblo simple, que bastante tiene con cumplir los mandamientosi89, y cuya mirada nunca penetrará en el arca santa, sino que, más bien, tendrá que soportar su peso190. El ideal de la "perfección cristiana" o, si se prefiere, del "cristiano perfecto" se había alejado (no sé si definitivamente) del pueblo.

Todavia debo indicar algo que, sin duda, es importante. He hablado anles del neoplatonismo, concretamente de la doctrina de Plotino. Hoy nadie duda de la decisiva in luencia que tuvo este autor en los fundadores del misticismo cristiano, concretamente en los llamados "padres de Capadocia" y, de manera especial, en Gregorio de Nisa191. Sabemos que, para los inspiradores decisivos de la

187. J. Quasten, Patrología, 1, p. 306, con bibliografía en pp. 306-307.

188. K. Koschorke, Die Polemik der Gnostiker gegen das kirchliche Christentum. Unter besonderer Berücksichsigung der Nag-Hammadi-Traktate "apokalipse des Petrus" (NHC VII, 3) und "Testimonium Veriratis" (NHC IX, 3), Leiden, 1978, p. 237.

189. Orígenes, In Psalm. XXVI, 3; In Ezech. VI, 6.

190. In Num. hom. IV, 3. Cfr. J. Lebreton, Les degrés de la connaissance religieuse d'après Origène, p. 294.

191. Como es sabido, fue determinante, a la hora de constatar este influjo, el estudio de J. Danićlou, Platonisme el Théologie Mystique. Essay sur la docirine spirituelle de Saint Grégoire de Nysse, Paris, 1944. Bibliografía sobre este asunto en J. Quasten, Patrología, II, Madrid, 1962 pp. 305-306. Además, H. Crouzel, "Grégoirc de Nysse est-il le fondateur de la Thćologie Mystique?", Rev_Asc.Myst. 33, 1957, pp. 189-202; J. Hochtaff, Negative Theologie. Ein Versuch zur Vermittlung des patristischen Begriffs, München, 1976; W. Jacger, Das frühe Christentum und die griechische Bildung, Berlin, 1963; A. Louth, The origines of the Christian Mystical Tradition, Oxford, 1981. 
mística cristiana, el ideal del creyente perfecto se alcanza en la "contemplación"192. Y que la contemplación exige, como condición indispensable, la separación de todo lo sensible incluso del cuerpo, para superar todas las pasiones 193. En definitiva, se trata de comprender que el ideal perfecto se alcanza mediante la "purificación". Pero teniendo presente que la purificación, tal como la entiende Plotino, puede llamarse "intelectualización"194. Ahora bien, la intelectualización "implica la participación de la vida divina"195. Y es un hecho que los autores cristianos, empezando por Gregorio de Nisa, compartieron este planteamiento, por más que lo entendieran como premio que Dios concede al que se purifical96.

Sólo me queda indicar algo que me parece evidente: si el ideal más alto, al que apuntaba la teología en el siglo IV, se alcanzaba en este grado de "intelectualización", está claro que el "vulgo vil", los "vencidos en la palestra del mundo", según las expresiones de Plotino, se veían, en la práctica y de hecho, condenados a no alanzar nunca el ideal de perfección que, ya entonces, enseñaban los teólogos.

\section{Conclusiones}

Se suelen dar distintas definiciones a la hora de explicar lo que es la teología. Una de esas definiciones dice que la teología es la reflexión sobre el mensaje cristiano. Ahora bien, al tratarse de un "mensaje", el contenido de cualquier teología está inevitablemente condicionado e incluso delerminado por dos cosas: desde dónde se emite ese mensaje y a quién se destina. Como es bien sabido, el "desde dónde" nos remite al lugar epistémico, es decir, desde qué "realidad histórica"197, o sea, desde qué vinculaciones, intereses y solidaridades ve uno la vida e interpreta la realidad. El "a quién" nos está diciendo que, obviamente, la condición de los destinatarios que aceptan un mensaje indica algo muy fundamental sobre su contenido. Esto supuesto, en la primera parte de este trabajo - al explicar la relación de Jesús con el pueblo-, quedó claro que el desde dónde del mensaje de Jesús (Ial como lo presentan los sinópticos) fue lo vida del pueblo.

192. Basilio, De Spiritu Sancro, IX, 23; Gregorio de Nacianzo, Orat. XXVIJI, 3; XX, L; Gregorio de Nisa, De beotitudinibus, orat. VI. Cfr. R. Arnou, "Platonisme des Pères", en Vacant-Mangenol, Dict.Théol.Cash. XII/2, p. 2310.

193. Gregorio de Nacianzo, Orat. XXI, 2; Gregorio de Nisa, De beatifudinibus, orat. V1.

194. Como se ha dicho muy bien, es cl proceso por cl que la psiché devienc noûs. Plotino, En. Vl, 9, 11, 23. Cfr. E. Borrego, op. cit., p. 85.

195. E. Borrego, op. cit., p. 85.

196. Ibid.

197. Se trata de los "pre-juicios" desde los que se interpreta la realidad. Porque "los prejuicios de cada individuo (son), mucho mas que sus juicios, la realidad histórica de su ser". H. G. Gadamer, Wahrheit und Methode, Tübingen, 1960, p. 261. 
Su solidaridad profunda y hasta visceral con el óchlos, las gentes de más baja condición social, económica, cultural y hasta religiosa de aquella sociedad. Desde ahí habló Jesús de Dios. Desde ahí explicó lo que es la fe en Dios. Y también la salvación y la esperanza, que deben orientar la existencia de los seres humanos. Por otra parte, sabemos que Jesús comunicó todo esto de tal manera que quienes lo aceptaron fueron precisamente aquellas gentes. $\mathrm{Y}$ lo aceptaron hasta el extremo de que ellas, no sólo siguieron a Jesús, sino que incluso fueron las que se solidarizaron con él y resultaron ser sus defensoras más eficaces ante las autoridades políticas y religiosas, cuando una y otra vez intentaron matarlo.

Todo esto quiere decir que el "mensaje" de Jesús se elaboró desde la vida. Concretamente, la vida del pueblo. Al decir esto, me refiero lógicamente a la situación, los condicionamientos y las circunstancias en que vivía la gente de más baja condición, que había en aquella sociedad. Y, además, lodo esto quiere decir también que el "mensaje" de Jesús se elaboró para dar respuesta a los problemas, las dificultades y los sufrimientos que llevaba consigo la vida del pueblo. Por supueslo, todos sabemos muy bien que ese "mensaje" hablaba de Dios, de la fe en Dios, de la salvación y de la esperanza que Dios concede a los seres humanos. Pero todo eso se puede explicar desde teorias, experiencias personales y especulaciones más o menos coherentes. Y se puede decir para que lo acepten los entendidos, los más cullivados y selectos. Sin embargo, sabemos con seguridad que Jesús no hizo nada de eso. Es decir, lo más hondo (y también lo más elocuente), que hay en el mensaje de Jesús no es sólo su contenido, sino además el mélodo o, si se prefiere, el modo como elaboró ese mensaje. Más aún, si realmente estamos convencidos de que Jesús fue un hombre, que vivió (como todos los hombres) determinado por los condicionamientos sociales y culturales que nos hacen pensar y hablar de una manera determinada, entonces resulta inevitable y hasta necesario decir que el método (o el modo con que) elaboró su mensaje determinó el contenido de lo que dijo en ese mensaje. En olras palabras, si Jesús hubiera nacido y vivido en solidaridad y sintonía con los grupos y estratos sociales y religiosos mejor situados de aquel tiempo, de aquella cultura y de aquella sociedad, es seguro (completamente seguro) que habría hablado del reino de Dios de una manera completamente distinta. Porque a nadie le cabe en la cabeza que un hombre, profundamente vinculado a los ambientes más selectos de la sociedad y de la religión, pudiera decir lo que dijo Jesús en sus sermones y parábolas. Por ejemplo, lo que dijo de los ricos (Lc 6, 24-25; 12, 13-21; 16, 14-31; Mc 10, 17-31 par; Mt 22, 5 par) y lo que dijo de los pobres (Lc 6, 20-21 par; Lc 14, 13; Mt 25, 31-46) incluso de los vagabundos y miserables que andan perdidos por la vida (MI 22, 9-10; Lc 14, 21-23; 15, 11-32). Lo que dijo de los "hombres de la religión" (Lc 10, 31-32; Mc 12, 1-12 par; MI 21, 28-31) y lo que dijo de los más entendidos, piadosos y observantes (Mc 12, 3840 par; Lc 18, 9-14; Mt 23, 1-36; Lc 20, 45-47). Y también lo que dijo de los herejes samaritanos (Lc 10, 25-35; 17, 11-19), de las prostitutas (Le 7, 36-50; 
Mt 21, 28-31) y hasta de los indeseables pecadores y publicanos (Mi 9, 10-13 par; Lc 7,$34 ; 15,1-2 ; 18,13 ; 19,7)$. Por último, es evidente que a un hombre de "buena sociedad" no se le ocurre decir que en el reino de Dios sólo pueden entrar los que se hacen como los últimos de este mundo, los que carecen de derechos y de estima, los "niños", ellos y nadie más que ellos (Mt 18, 2-5; Mc 10, 13-15; Lc 18, 16-17). Como tampoco se le ocurre arremeter contra los que gobiernan, llamándoles "dominadores" y "opresores" (Mc 10, 42 par).

$Y$ es importante caer en la cuenta que Jesús dijo estas cosas de manera que sorprendieron e incluso resultaron intolerables, no sólo para los ricos, los clérigos y los dignatarios de su tiempo, lo cual es comprensible. Lo más chocante es que buena parte de esta doctrina resultó inaceplable también para sus mismos discípulos, como ya demostré en la primera parte de este trabajo. Sin duda alguna, Jesús transmitió un mensaje que no era para "selectos". Para selectos de ningún tipo ni de ninguna clase. Porque iba derechamente a tirar por tierra cualquier pretensión de situarse por encima de otros, fuera quien fuera. Y por el motivo que fuera. Aunque se tratara de las inconfesables (y probablemente inconscientes) pretensiones de los "discípulos" de ser ellos los más dignos, los primeros y los que iban a llevar la voz cantante en el reino de Dios. Por eso y nada más (ni nada menos) que por eso, Jesús se solidarizó y vivió en la más profunda comunión con el "pueblo" (óchlos). Sin duda, eso no fue ocasional. Ni lo hizo para "dar ejemplo". Las cosas ocurtieron como ocurrieron porque sólo desde abajo, desde la solidaridad con lo más bajo, se puede hablar correctamente del Dios de Jesús. Y no es que Jesús "instrumentalizara" al pueblo, para así poder hablar bien de Dios. Se trata de algo más elemental y menos alambicado. Se trata de comprender que sólo desde lo único bueno que pueden tener los que están abajo en la historia, que es cariño (porque lo necesilan mucho), sólo desde ahí nos podemos empezar a enterar de lo que realmente es eso a lo que Jesús llamaba $A b b a$, Padre.

En segundo lugar, ningún cristiano puede poner en duda que san Pablo elaboró y transmitió un "mensaje", una teología, que ha sido, es y será decisiva para los creyentes de todos los tiempos. De manera que la Iglesia no sería, ni podría ser, la Iglesia que Dios ha querido, si careciera de la teología que nos dejó san Pablo. Con esto quiero decir que la Iglesia no sería la Iglesia que Dios quiere, si no conociera la teología de Cristo resucitado que nos enseñó Pablo. Y si no conociera la teología de la "justificación" y de la fe, tal como la presenta Pablo. O la teología de la libertad cristiana, de los carismas y de los ministerios, que nos han transmitido las cartas de Pablo. Por eso, para cualquier cristiano, que sepa lo que dice, no tienen sentido alguno las intemperantes acusaciones de Nielzsche, cuando afirma que Pablo es lo más opuesto al "portador de la Buena Nueva", el "genio del odio, de la visión del odio, de la lógica inexorable del 
odio"198. Ni tampoco son ya de recibo los gastados tópicos que, de una manera o de otra, nos vienen a decir que hay que volver a Jesús, abandonando el "cristianismo paulino"199. No y mil veces no. Porque, entre otras cosas, sin la teología de Pablo tendríamos lagunas y oscuridades en nuestra fe, que seguramente serían insalvables.

Y sin embargo, nadie discute (ni puede disculir) que el mensaje de Pablo es muy distinto del mensaje que, según los sinópticos, nos transmitió Jesús. Por supuesto, en la teología de Pablo se dicen cosas que no están en la teología de los evangelios. Pero el problema que plantean las nuevas aportaciones de Pablo no se resuelve analizando los contenidos nuevos que, sin duda, hay en sus cartas. Y menos aún contraponiendo esos contenidos a la enseñanza de los evangelios. El problema que todo esto plantea se empieza a comprender cuando se piensa en el método que utilizó Pablo a la hora de aportar esos nuevos contenidos. Quiero decir: el serio problema que empezó a plantearse a la teología cristiana a partir de las cartas paulinas no está en que Pablo dijo cosas que no están en los evangelios, sino que está en el desde dónde y el para quién elaboró su teología. Porque, como ha quedado bien claro en este trabajo, Pablo no construyó su teología desde la vida, la situación y el sufrimiento del pueblo. No sabemos si eso le preocupó o no le preocupó cuando se puso a pensar en Dios y a hablar de Dios. Seguramente le tuvo que preocupar. Pero el hecho es que Pablo no consideró que ese asunto tuviera que ver con su teología. Por la sencilla razón de que en sus escritos no menciona al "pueblo" sin más (óchlos o démos) ni una sola vez. Pablo habla con frecuencia del "pueblo de Dios" (laós theoû). Y habla de los "pueblos paganos" (éthne). Pero, como es bien sabido, en esos casos se trata ya de "conceptos teológicos", relacionados con los problemas que tuvo la Iglesia naciente con el judaísmo y los gentiles.

Entonces, ¿desde dónde pensó y escribió Pablo su teología? Es algo bien conocido: desde su "experiencia personal" (Gal 1, 15-17; 1Cor 9, 1; 15, 8). La experiencia de su conversión. Una experiencia intima y, por tanto, con una fuerte carga de subjetividad, centrada inevitablemente en la subjetividad. $Y$ además repensada en la soledad, "sin consultar con nadie" (Gal 1, 16-17) durante tres años (Gal 1, 18). Por otra parte, ipara quién pensó y escribió Pablo su teología? Lo expliqué antes. La pensó y la escribió para comunidades de creyentes en las que había "sabios", "poderosos" y "gentes de buena familia" junto con "ignorantes", "plebeyos" y personas "despreciadas". Además, hay dalos que prueban que los de más elevada situación eran precisamente los que más influían en la comunidad, los "sabios". De ahí, la importancia que tienen, en las cartas de

198. F. Nietzsche, El Anticristo, Madrid, 1969, p. 70.

199. Cfr. en cste scnlido, por ejemplo, W. Wredc, Paulus, Tübingen, 1907, p. 94; R. Bultmann, Glouben und Verstehen I, Tübingen, 1966, p. 191. 
Pablo, los "sabios", sóphoi (Rom 1, 14.22; 16, 19.27; 1Cor 1, 19.20.26.27; 3, 10.18.19.20; 6, 5; Ef 5, 15) y la "sabiduria", sophía (Rom 11, 33; 1Cor 1, 17.19.20.21.22.24.30; 2, 1.4.5.6.7.13; 12, 8; 2Cor 1, 12; Ef 1, 8.17; 3, 10; Col 1, $9.28 ; 2,3.23 ; 3,16 ; 4,5)$. Y como ya expliqué antes, sabemos que el lenguaje y la problemática relacionada con los sóphoi era tema caracteríslico de los estoicos, a partir del cual dividían a los hombres en dos categorías de personas, los "sabios" (ricos y virtuosos) y los "villanos" (phauloi, pobres y viciosos). Por supuesto, Pablo no divide así a los crislianos de sus comunidades. Porque, a partir de su "leología de la cruz", destaca con fuerza que el Dios cristiano se ha revelado precisamente en "lo necio", "lo débil", "lo plebeyo", "lo despreciado", "lo que no existe" (1 Cor 1, 27-29). Pero, justamente por eso, aquí es donde se ve con más claridad la inevitable confusión en que puede encontrarse el lector de las cartas de Pablo. Que es la confusión en que puede encontrarse el lector de no pocas teologías posteriores a él. Porque, junto al elogio de la debilidad y la necedad, Pablo desea que los cristianos sean "sabios" (Rom 16, 19; 1Cor 3, $10.18 ; 6,5 ;$ Ef 5, 15). Sabios "para lo bueno", eis tó agathón (Rom 16, 19), eso desde luego. Pero, a fin de cuentas, sóphoi, el ideal de los estoicos.

Por otra parte, como ya he dicho, Pablo tuvo que hacer su teología de manera que pudiera resultar aceplable para gentes que iban, desde las personas más distinguidas, hasta los de más baja condición, incluidos los esclavos. Y es claro, ahí ya no cabía el radicalismo social de las parábolas del reino que nos cuentan los evangelios. La salida de Pablo fue insistir en el "patriarcalismo del amor", el amor que acepla las diferencias sociales y de todo tipo. Y lambién insistir en el comportamiento "moral", que se centra en el dominio de las "pasiones" (Rom 1, 26; Col 3, 5; 1Tes 4, 5) y, sobre lodo, en vencer el "deseo", epishymía (Rom 1, $24 ; 6,12 ; 7,7.8 ; 13,14 ;$ Gal 5, 16.24; Ef 2, 3; 4, 22; Fil 1, 23; Col 3, 5; 1Tes 2, $17 ; 4,5$ ), del que brolan (según la moral esloica) los abundantes vicios que Pablo señala como los comportamientos que hay que rechazar para "heredar el reino de Dios" (1Cor 6, 9-10; 15, 50; Gal 5, 19-21; Ef 5, 3-5).

El problema que nos plantea la teología de Pablo, cuando la comparamos con la teología de los evangelios, no está en que diga cosas que no están en el mensaje de Jesús. Ya he dicho que esas cosas han enriquecido y siguen enriqueciendo a la Iglesia. El problema está en que Pablo dijo esas cosas desde una subjetividad y para unos destinatarios que ya no eran el desde y el para en que se situó Jesús. Ahora bien, eso vino a ser un modo de hacer teologia distinto del modo que tuvo Jesús al hablar de Dios. Pero entonces, ese nuevo modo de hablar de Dios no pudo tener más salida que poner el acento en el "subjetivismo" y el "intelectualismo", que hoy mismo siguen poniendo en evidencia tantos libros de buena (muy buena) teología. $Y$ es que, si no me equivoco, cuando la teología se desvincula de la vida, concretamente de la vida de los que más sufren en la vida, tiene el serio peligro de bloquearse en la especulación intelectual (las grandes verdades) y en el equilibrio de la subjetividad (ascesis). 
En tercer lugar, la teología cristiana nació en el mundo de la cultura helenista. Y en esa cultura se desarrolló durante más de cinco siglos. Más aún, no sólo se desarrolló en aquella cultura, sino que, por lo menos desde Orígenes, se intentó aunar fe crisliana y cultura helenista. Ahora bien, las cuatro grandes corrientes de pensamiento que más decisivamente determinaron lo que hoy llamamos el "helenismo", fueron la filosofía de Platón, el estoicismo, el gnosticismo y el neoplatonismo de Plotino. Eslo supuesto, debo confesar que, a lo largo de este trabajo, lo que más me ha impresionado ha sido comprobar hasta qué punto esas cuatro grandes corrientes de pensamiento coincidieron en dos cosas. Por una parte, la profunda religiosidad200 que va desde Platón hasta Plotino y que desemboca en la misteriosa coincidencia de la filosofía con la mística, tal como aparece en las Enéadas. Por otra parte, el profundo desprecio del pueblo, que aparece ya en la República de Platón, cuando designa al pueblo como la "gran bestia", que se acentúa en los phauloi ("villanos"), a los que desprecian los estoicos, que se prolonga en los "ignorantes" de los que no quieren saber nada los gnósticos, los que pertenecian a los "grupos elitistas basados en el conocimiento", y que llega hasta el "pueblo despreciable", los "vencidos en la palestra del mundo", como dice el gran místico que fue Plotino.

Por supuesto, a mí no me sorprende que los pensadores de aquellos tiempos despreciaran al pueblo. Lo que me hace pensar es la asociación entre "religión" y "desprecio". Sobre todo, cuando lo que se desprecia no son cosas, sino personas, concretamente las personas más desvalidas de la sociedad. Y más aún, cuando se las desprecia precisamente por motivos religiosos, ya sea porque se trata de gente ignorante, que no entiende de los altos misterios de la religión, ya sea porque son personas que no praclican la virtud, que fue sin duda el motivo más fuerte por el que, desde Platón hasta Plotino, se justificó el desprecio del pueblo. Debe haber en todo esto una misteriosa relación en la historia de las ideas y las experiencias religiosas. Porque no puede ser casual que, en la sociedad en que vivió Jesús, los hombres más religiosos se considerasen a sí mismos como los "puros" y los "dignos" (heber) y despreciaran al "pueblo" (óchlos) los "impuros" (ámme haArez). Como tampoco puede ser casualidad que Jesús, precisamente por identificarse con el pueblo, se viera despreciado y rechazado por los estamentos dirigentes de la religión.

Todo esto hace pensar. No es éste ni el sitio ni el momento de ponerse a analizarlo. Me limilo simplemente a expresar que mi mayor sorpresa ha sido constatar que las ideas del helenismo fueron, en gran medida, asimiladas por los

200. También el estoicismo de Zenón y los primeros estoicos de Atenas fue profundamente religioso, por más que resulte problemático identificar la razón o la naturaleza con Dios. Pero no en vano se ha calificado al estoicismo como "una religiosidad sin Dios", como reza el título del estudio de M. Daraki, citado repetidas veces. 
creadores de la teología cristiana incluyendo incluso, en no pocos casos, el desinterés y, a veces, el desprecio por el pueblo.

En cuarto lugar, cualquiera que haya estudiado la historia de la teología cristiana sabe que ésta se orientó muy pronto por los caminos de la alta especulación. A. Orbe, al presentar su excelente Introducción a la teologla de los siglos $/ /$ y $I I I$, explica cómo en el siglo II se enfrentaron dos teologías, la herética (gnóstica) y la eclesiástica. Y de ambas dice que son tan "difíciles y oscuras", que "se aclaran mejor por el análisis mutuo — en contraste- que por sí solas"201. Inevitablemente, este estado de cosas provocó cuatro consecuencias, que han marcado profundamente a la teología desde entonces: la teología se distanció, cada vez más y más, del pueblo, de la gente vulgar y sencilla, de sus preocupaciones cotidianas y de sus intereses, llegando (en ocasiones) a mostrar hasta un mal disimulado menosprecio por los ignorantes y los sencillos; por eso mismo, la teología se alejó también de la vida, de lo que ocurría en la sociedad, elevándose a la especulación de problemas que poco o nada tenían que ver con lo que pasa en este mundo; el centro de la vida cristiana dejó de ser el reino de Dios, tal como lo presentan los evangelios, y en su lugar se vino a poner lo que era precisamente el centro del ideal helenista, la areté ("virlud"). Y no es que no se mencionara lo del reino. Lo que ocurrió es que se hablaba de ese asunto de manera que, lo que se decía, nada tenía que ver con lo que predicó Jesús. Por ejemplo, es sorprendente que el espléndido banquete ofrecido por Constantino en su palacio, a los obispos participantes en el concilio de Nicea, es presentado por Eusebio de Cesarea como la realización del reino de Dios en este mundo202. Por otra parte, que la virtud vino a ocupar el centro de la vida cristiana, es la consecuencia que se siguió inevitablemente desde el momento en que se asumió el moralismo estoico como el modelo a imitar por los creyentes. Esto aparece ya perfectamente asumido por Orígenes, para quien la práctica de las virtudes nos hace participar de la vida de Cristo y perfeccionar su imagen en nosotros 203. De esta manera, el esquema de las cuatro virtudes cardinales, definitivamente clasificado por los estoicos 204 , se constituyó en el proyecto fundamental de la vida de fe. Pero no olvidemos que la areté del helenismo se distancia hasta tal punto del ideal evangélico del reino que, como ya dije, los estudio-

201. A. Orbe, Introducción a la teologla de los siglos II y III, Roma-Salamanca, 1988, p. 6.

202. Vira Const. 3, 14.

203. Así lo ha demostrado ampliamente H. Crouzel, Theologie de l'image de Dieu chez Origene, París, 1956, pp. 239ss. Cfr. T. Spidlik, "Virtudes y vicios", en A. di Berardino (ed.), Diccionario Patrístico y de la antigüedad cristiana, vol. II, Salamanca, 1992, pp. 2216-2217, con bibliograffa.

204. Se trata de la "prudencia" (phrónesis), "justicia" (dikaiosyne), "fortaleza" (andreia) y "templanza" (sophrosyne). SVF I, Pp. 200-201; III, pp. 262-264. 
sos de Platón dudan, con frecuencia, si traducirla por "virtud" o por "excelencia". Se trata, en efeclo, de la capacidad que da "fuerza", "vigor", "éxito" y "progreso"20s. Finalmente, la teología desembocó así en un ideal de interioridad o, más exactamente, de "subjetividad", que poco o nada tiene que ver con el cambio de la sociedad y la historia. Porque la "virtud" se conseguía en la medida en que el sujeto dominaba sus "pasiones" y ordenaba sus "deseos". Desde entonces, la teología fue asunto de "selectos" y para "selectos", ya se tratase del elitismo de los intelectuales, de los que detentan el poder (sobre todo el religioso) y de los que sobresalen por su virtud. A poco que se piense, todo esto anda ya demasiado lejos de aquello que hizo y dijo Jesús de Nazaret.

205. Cfr. H. Frisk, Griechisches Etymologisches Wörterbuch, I, Heidelberg, 1973, p. 137; H. J. Snell, Lexikon des Frühgriechischen Epos, I, Göttingen, 1955-1978, pp. 1229-1232. 